\title{
Water-melt interaction in hydrous magmatic systems at high temperature and pressure
}

\author{
Bjorn Mysen
}

\begin{abstract}
Experimental data on the structure and properties of melts and fluids relevant to water-melt interaction in hydrous magmatic systems in the Earth's interior have been reviewed. Complex relationships between water solubility in melts and their bulk composition [Al/Si-ratio, metal oxide/(Al + Si) and electron properties of metal cations] explain why water solubility in felsic magmas such as those of rhyolite and andesite composition is significantly greater than the water solubility in basalt melts. The silicate solubility in aqueous fluid is also significantly dependent on composition with metal oxide/(Al $+\mathrm{Si})$ and electron properties of the metal cations, the dominant variables. Hydrogen bonding is not important in hydrous fluids and melts at temperatures above $500^{\circ} \mathrm{C}$ to $550^{\circ} \mathrm{C}$ and does not, therefore, play a role in hydrous magmatic systems. The properties of hydrous melts and aqueous solutions are governed by how the silicate speciation $\left(Q^{n}\right.$ species, where $n$ is the number of bridging oxygen in an individual species) varies with bulk composition, silicate composition, temperature, and pressure. The reactions that describe the interactions are similar in melts, fluids, and supercritical fluids. The degree of melt polymerization caused by dissolved water varies with melt composition and total water content. Silicate- and alkali-rich felsic magmatic melts are more sensitive to water content than more mafic magmas. Transport and configurational properties of hydrous magmatic melts can be modeled with the aid of the $Q^{n}$ speciation variations. Liquidus and melting phase relations of hydrous systems also can be described in such terms, as can minor and trace element partition coefficients. Stable isotope fractionation (e.g., $\mathrm{D} / \mathrm{H}$ ) can also be rationalized in this manner. Critical to these latter observations is the high silicate concentration in aqueous fluids. These components can enhance solubility of minor and trace elements by orders of magnitude and change the speciation of $\mathrm{H}$ and $\mathrm{D}$ complexes so that their fractionation factors change quite significantly. Data from pure silicate- $\mathrm{H}_{2} \mathrm{O}$ systems cannot be employed for these purposes.
\end{abstract}

Keywords: Hydrous magma; Aqueous fluid; Melt structure; Viscosity; Isotope partitioning; Partial melting; Water solubility; Silicate solubility; Glass transition; Solution mechanism

\section{Review Introduction}

The principal mass and energy transport agents in the Earth are magmatic melts and water-rich fluids. Their transport properties are sensitive to their water and silicate content. Experimental characterization of solubility and solution mechanisms of water and silicate components is, therefore, central to our understanding of magmatic and metasomatic processes in the Earth's interior.

Properties of magmatic melts are sensitive to their water content as first noted by Spallanzani (1798). Perhaps the most well-known among these effects is a several hundred

Correspondence: bmysen@ciw.edu

Geophysical Laboratory, Carnegie Institution of Washington, 5151 Broad Branch Rd., NW, Washington DC 20015, USA degree centigrade temperature depression at high pressure of solidii and liquidii of silicate phase assemblages (including natural mineral assemblages) (e.g., Kushiro et al. 1968a, b; Grove et al. 2012). Liquidus phase relations (including partial melt compositions), transport, and volume properties of hydrous melts also vary in important ways with variations in water content (Kushiro 1972; Richet et al. 1996; Ochs and Lange 1999; Grove et al. 2003).

Aqueous solutions in the Earth's interior are efficient solvents of oxide components (Zhang and Frantz 2000; Manning 2004). Several mol\% of silicate components dissolve under conditions corresponding to those of the deep continental crust and upper mantle. In the upper mantle, there can be complete miscibility between $\mathrm{H}_{2} \mathrm{O}$ and silicate (Bureau and Keppler 1999; Mibe et al. 2007). 
Major element solutes in aqueous fluids (silicate components) can also enhance the solubility of other components by up to orders of magnitude (Pascal and Anderson 1989; Antignano and Manning 2008; Mysen 2012a, b; Ayers and Watson 1993). Transport, volume, and mixing properties of silicate-rich aqueous fluids differ in important ways from those of pure $\mathrm{H}_{2} \mathrm{O}$ (Audetat and Keppler 2004; Hunt and Manning 2012; Hack and Thompson 2012; Foustoukos and Mysen 2013).

The property behavior of melts and fluids in hydrous silicate systems at the high temperatures and pressures can be traced to the relationships between fluid and melt structure and their properties. Most experimental and theoretical studies have focused on the behavior in chemically simpler systems in order to isolate the effects of individual intensive and extensive variables. With the information from chemically simpler systems, we can model melt and fluid behavior in systems relevant to natural processes. In this review, these relationships will be presented and their applications to natural systems will be discussed.

\section{Water and properties of hydrous magma Melting phase relations}

The solidus temperature depression of mantle peridotite caused by $\mathrm{H}_{2} \mathrm{O}$ ranges between approximately $1200^{\circ} \mathrm{C}$ and approximately $1600^{\circ} \mathrm{C}$ at the upper mantle pressures (Figure 1A). The water solubility in partial melts from a peridotite parent in this pressure range is 20 to $40 \mathrm{wt} \%$ (Hamilton et al. 1964; Holloway and Jakobsson 1986). Furthermore, the extent of the solidus temperature depression depends on silicate composition and increases, for example, with increasing silica content (Figure 1B). In natural systems, this effect helps explain why the liquidus depression caused by $\mathrm{H}_{2} \mathrm{O}$ of a felsic composition (e.g., granitic composition) is greater than that of peridotite (Figure 1A). An implication of these observations is that in a subduction zone water has a greater effect on solidus temperature of descending crustal material near the slab/ peridotite interface than in an overlying peridotite wedge or in an underlying depleted oceanic lithosphere $\left(200^{\circ} \mathrm{C}\right.$ to $300^{\circ} \mathrm{C}$ temperature difference; Kushiro et al. 1968b; Grove et al. 2012).

The composition of a melt in equilibrium with silicate mineral assemblages at high pressure is affected by $\mathrm{H}_{2} \mathrm{O}$ (Figure 2). For example, at 2 to $3 \mathrm{GPa}$, in equilibrium with enstatite + diopside + forsterite in the $\mathrm{CaMg}_{2} \mathrm{O}_{6}$ $\mathrm{Mg}_{2} \mathrm{SiO}_{4}-\mathrm{SiO}_{2}$ system, the melt is quartz normative in the presence of $\mathrm{H}_{2} \mathrm{O}$ and olivine normative under volatile-free conditions (Kushiro 1969). In natural peridotite systems, this difference persists so that partial melting of hydrous peridotite at least to $2 \mathrm{GPa}$ is quartz normative (andesite or quartz tholeiite), whereas anhydrous peridotite melting under these conditions results in olivine tholeliite (Kushiro 1990). The silica content of partial melts is not, however, the only compositional variable affected by $\mathrm{H}_{2} \mathrm{O}$ at high pressure and temperature. This is evident in the system $\mathrm{NaAlSi}_{3} \mathrm{O}_{8}-\mathrm{KAlSi}_{3} \mathrm{O}_{8}-\mathrm{SiO}_{2}$ system (Figure 2B). Here, increasing water pressure (which means increasing concentration of $\mathrm{H}_{2} \mathrm{O}$ in the melt) leads to a rapid expansion of the quartz liquidus volume relative to that of feldspar components. This evolution means increasing alumina/
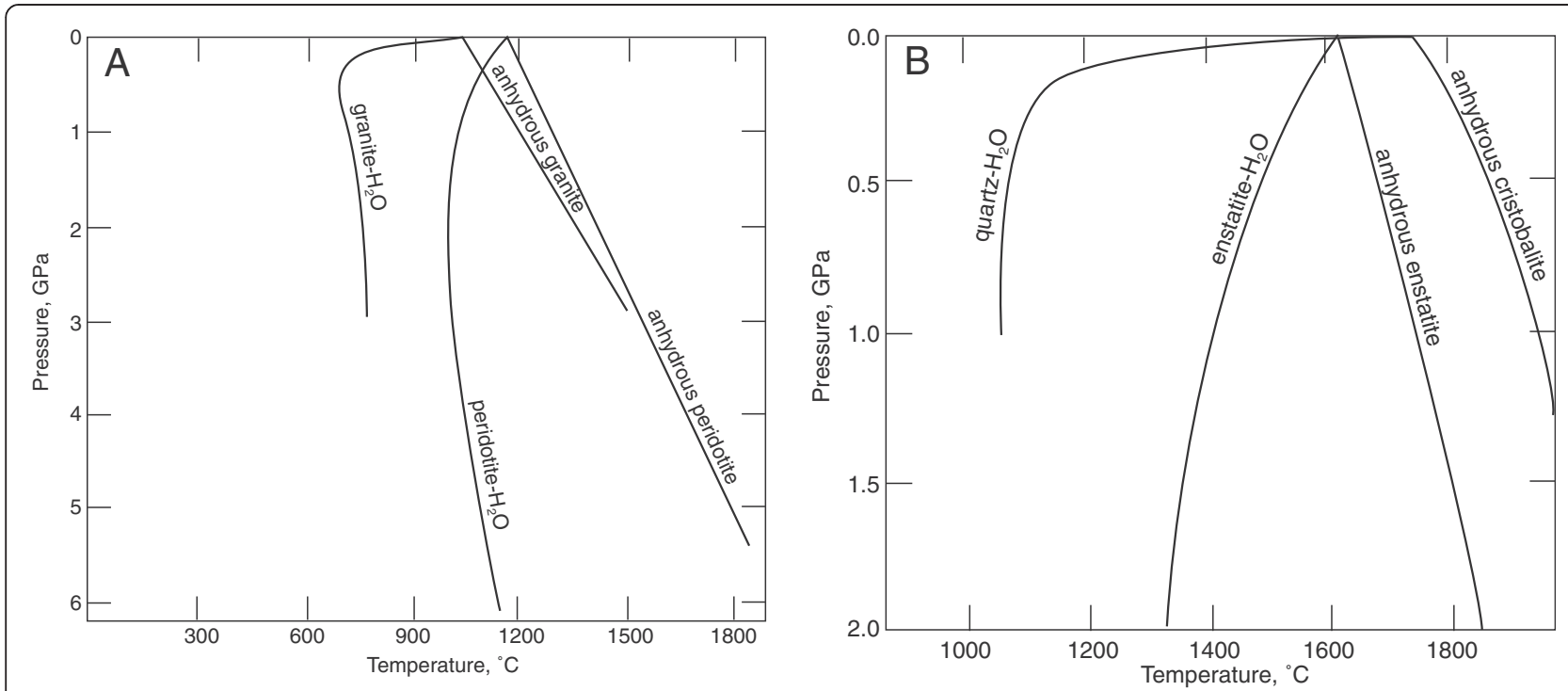

Figure 1 Pressure/temperature trajectories. (A) Granite with and without $\mathrm{H}_{2} \mathrm{O}$ (granite- $\mathrm{H}_{2} \mathrm{O}$ and anhydrous granite) and peridotite with and without $\mathrm{H}_{2} \mathrm{O}$ (peridotite- $\mathrm{H}_{2} \mathrm{O}$ and anhydrous peridotite) solidi (Stern et al. 1975; Kushiro et al. 1968a) and (B) silica polymorphs and enstatite with and without $\mathrm{H}_{2} \mathrm{O}$ (cristobalite- $\mathrm{H}_{2} \mathrm{O}$, enstatite- $\mathrm{H}_{2} \mathrm{O}$, anhydrous cristobalite, and anhydrous enstatite) (Boyd et al. 1964; Kushiro et al. 1968a; Jackson 1976; Boettcher 1984). 


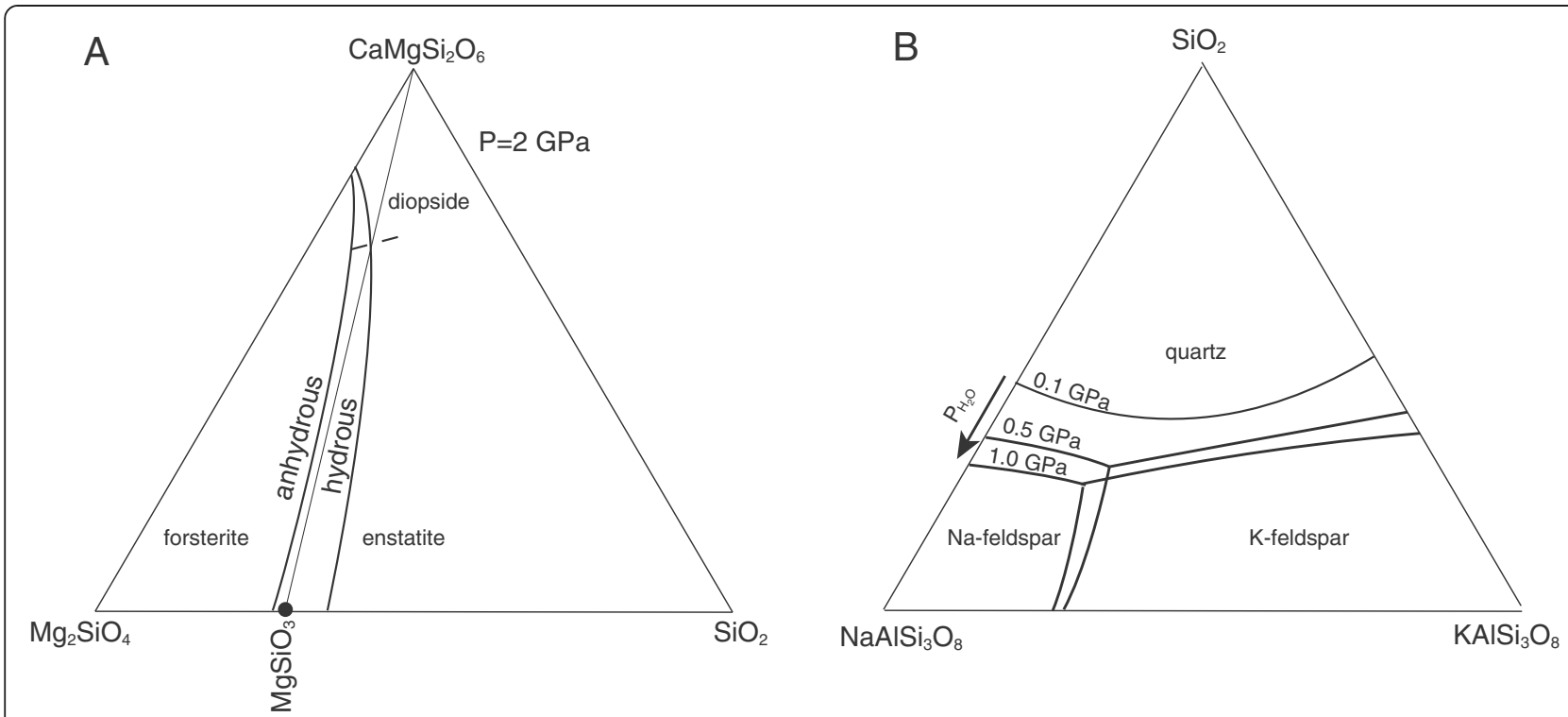

Figure 2 Liquidus phase relations in hydrous and anhydrous silicate and aluminosilicate systems. (A) Pyroxene/olivine liquidus boundary at $2 \mathrm{GPa}$ in the $\mathrm{Mg}_{2} \mathrm{SiO}_{4}-\mathrm{CaMgSi}_{2} \mathrm{O}_{6}-\mathrm{SiO}_{2}$ system with and without $\mathrm{H}_{2} \mathrm{O}$ from Kushiro (1969). (B) Evolution of feldspar/quartz liquidus boundaries in the $\mathrm{NaAlSi}_{3} \mathrm{O}_{8}-\mathrm{KalSi}_{3} \mathrm{O}_{8}-\mathrm{SiO}_{2}$ system with increasing $\mathrm{H}_{2} \mathrm{O}$ pressure compared with anhydrous $0.1 \mathrm{MPa}$ liquidus boundaries $\mathrm{H}_{2} \mathrm{O}$ (data from Tuttle and Bowen 1958; Luth et al. 1964)

silica ratio in hydrous melts derived from partial melting of pelagic sediments compared with melting products of hydrous oceanic basaltic crust in the upper portion of subducting plates the higher the water content (see, for example, Poli and Schmidt 2002).

\section{Properties of hydrous silicate melts}

Transport properties of silicate melts (e.g., viscosity, diffusion, conductivity) are quite sensitive to their water content. For example, melt viscosity decreases by several orders of magnitude by a solution of as little as $1 \mathrm{wt} \%$ $\mathrm{H}_{2} \mathrm{O}$ (Richet et al. 1996). This effect, however, is strongly non-linear and diminishes with increasing water content (Figure 3A). Furthermore, deviation of melt viscosity from Ahrrenian behavior is increasingly pronounced the higher the water content (Figure 3B). Water effects on viscosity are more pronounced the more felsic the melt. Water effects also are more pronounced the higher the alkali/alkaline earth ratio. This means that the viscosity of rhyolitic melts is more sensitive to water content than basalt and that alkali basalt is more sensitive to water content than olivine tholeiite.

Most other physical properties of silicate melts show analogous relations with water content and silicate composition. Examples include cation and water diffusion in melts (Watson 1994; Behrens and Nowak 1997), effects of water on glass transition temperature (Richet et al. 1996, 1997; Whittington et al. 2000), and electrical conductivity (e.g., Takata et al. 1981; Satherley and Smedley 1985). These effects exist because of the functional relationships that exist between these transport properties (Nernst 1888; Einstein 1905; Eyring 1935a, b).

\section{Water solubility in magmatic melts}

In order to understand better the solubility behavior of $\mathrm{H}_{2} \mathrm{O}$ in silicate melts and the silicate solubility in aqueous solutions, examination of schematic phase relations in silicate- $\mathrm{H}_{2} \mathrm{O}$ systems can be helpful (Figure 4). There exists a range of pressures and temperatures where $\mathrm{H}_{2} \mathrm{O}$-saturated silicate melts and silicate-saturated aqueous fluids coexist ('melt + fluid' field in Figure 4). This boundary defines the water solubility in the silicate melts. The boundary between 'aqueous fluid' and 'silicate melt + aqueous fluid' describes the silicate solubility in aqueous fluid. At temperatures above the solvus (above the critical point (c.p.) in Figure 4), there is complete miscibility between silicate melt and aqueous fluid. The temperature/ pressure coordinates of the critical point ranges from about $1 \mathrm{GPa}$ near $1,200^{\circ} \mathrm{C}$ for granitic compositions to nearly $4 \mathrm{GPa}$ near $1,200^{\circ} \mathrm{C}$ for peridotite- $\mathrm{H}_{2} \mathrm{O}$ (Bureau and Keppler 1999; Mibe et al. 2007). The slope of the phase boundaries at lower temperatures depends on pressure and temperature itself (Holtz et al. 1995).

It follows that water solubility in magmatic melts is temperature, pressure, and silicate composition dependent. The water solubility in melts in the simplest of silicate systems, $\mathrm{SiO}_{2}-\mathrm{H}_{2} \mathrm{O}$, at low pressures is a linear function of the square root of water fugacity, $\sqrt{ } f_{\mathrm{H}_{2} \mathrm{O}}$ (Moulson and Roberts 1961; see Figure 5A). However, with increasing pressure 

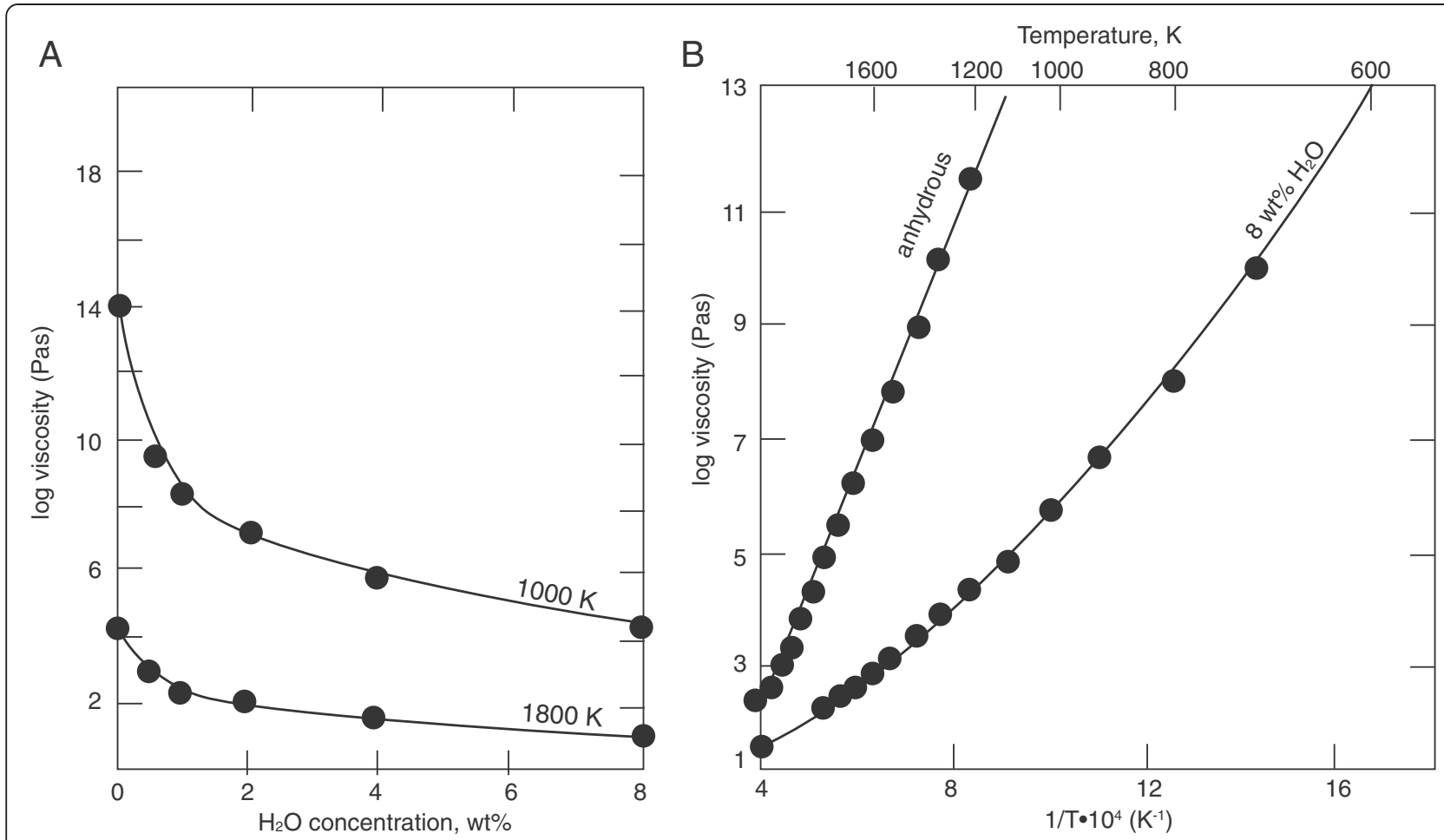

Figure 3 Viscosity of silicate melts as a function of their total $\mathrm{H}_{2} \mathrm{O}$ content and temperature. (A) Hydrous andesite melt viscosity from Richet et al. (1996) recorded at ambient pressure by using a sample synthesized at $400 \mathrm{MPa}$ and $1400^{\circ} \mathrm{C}$ before viscosity measurement at ambient pressure and temperatures indicated. (B) Temperature-dependence of melt viscosity of granite composition with (8 wt $\%$ ) and without $\mathrm{H}_{2} \mathrm{O}$ as indicated on curves from Hess and Dingwell (1996).

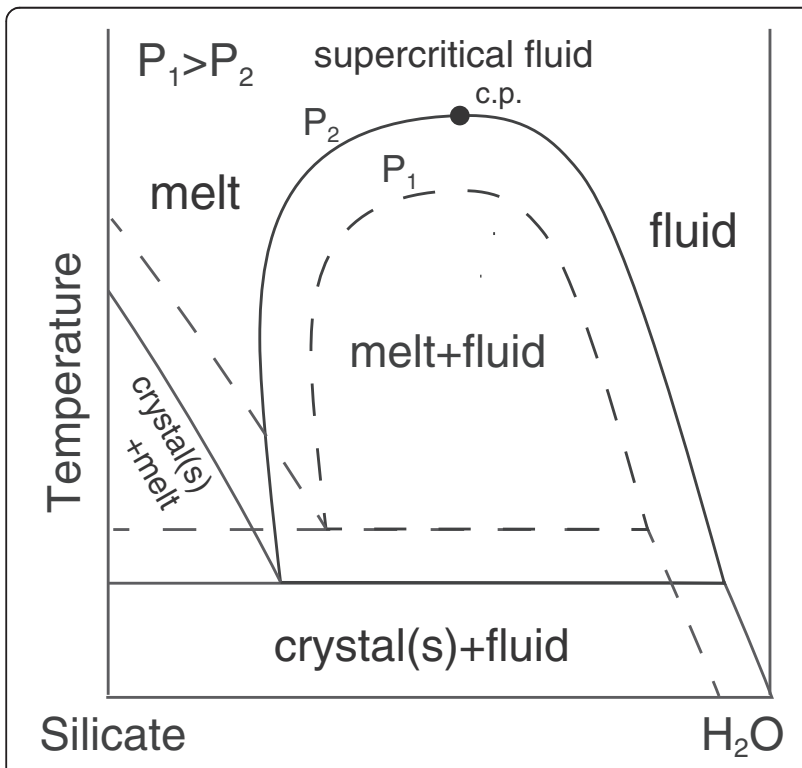

Figure 4 Schematic and simplified phase relations in silicate- $\mathrm{H}_{2} \mathrm{O}$ systems at two different pressures, $P_{1}$ and $P_{2}$, where $P_{1}>P_{2}$. (and $f_{\mathrm{H}_{2} \mathrm{O}}$ ), the solubility is a non-linear function of $\sqrt{ } f_{\mathrm{H}_{2} \mathrm{O}}$ (Figure 5) and where the pressure dependence itself is pressure dependent (Kennedy et al. 1962; see Figure 5B).

The features in Figure 5 notwithstanding, the pressure dependence of water solubility in more complex melts, including natural basalt and other aluminosilicate compositions, shows no simple solubility relationship with pressure (or $f_{\mathrm{H}_{2} \mathrm{O}}$ ) (Figure $5 \mathrm{C}$ ). These complex relations likely reflect several effects on the solubility of $\mathrm{H}_{2} \mathrm{O}$ of individual silicate components. For example, in ternary metal oxide aluminosilicate systems, water solubility is correlated with metal/Si and $\mathrm{Al} / \mathrm{Si}$ ratios and electronic properties of the metal cation (Kurkjian and Russell 1958; Behrens et al. 2001; Mysen and Cody 2004; see also Figure 6). At high metal oxide/silica ratio, the water solubility decreases as this ratio increases, but this relationship reverses near composition where alkali metal/Si ratio is near 1 (Kurkjian and Russell 1958). Furthermore, whereas water solubility in peralkaline silicate melts decreases with increasing $\mathrm{Al} / \mathrm{Si}$ ratio (Figure $6 \mathrm{~B}$ ), the reverse relationships have been observed for melts along $\mathrm{SiO}_{2}-\mathrm{NaAlO}_{2}$ (metaaluminosilicate) joins (McMillan and Holloway 1987).

Given the complex relationships between melt composition and water solubility, it is not surprising that 

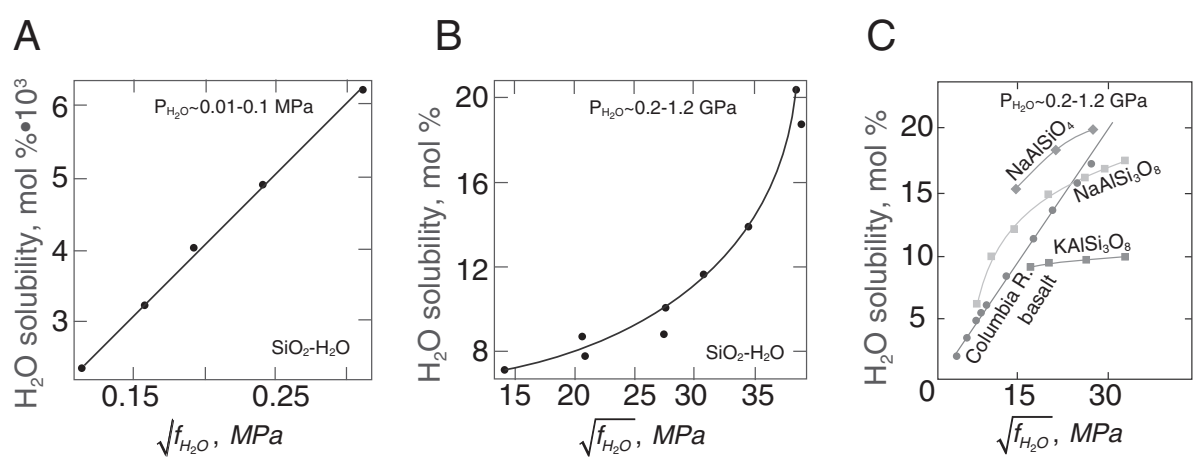

Figure $5 \mathrm{H}_{2} \mathrm{O}$ solubility in silicate melts at low and high pressures as a function of fugacity of $\mathrm{H}_{2} \mathrm{O}, \boldsymbol{f}_{\mathrm{H}_{2}} \mathrm{O}$. (A) Solubility in $\mathrm{SiO}_{2}$ melt at and below ambient pressure from Moulson and Roberts (1961). (B) Solubility in $\mathrm{SiO}_{2}$ melt at high pressure as a function of $f_{\mathrm{H}_{2} \mathrm{O}}$ from Kennedy et al. (1962). (C) Solubility in various silicate melts as a function of $f_{\mathrm{H}_{2} \mathrm{O}}$ as compiled by McMillan (1994).

the solubility varies significantly in different magmatic systems. In general, water solubility in felsic magmas such as those of rhyolite and andesite composition is significantly greater than the solubility in basalt melts (Hamilton et al. 1964; Dixon and Stolper 1995; Behrens and Jantos 2001; Zhang 1999). This would be expected because of the higher alkali/alkaline earth and $\mathrm{Si} / \mathrm{Al}$ ratios in rhyolite and andesite melt compared with melts of basaltic composition. These solubility relationships have been modeled with a variety of empirical models (e.g., Spera 1974; Burnham 1975; Dixon and Stolper 1995; Behrens and Jantos 2001). However, quantitative linkage between solubility behavior in chemically simple melts and more complex natural magma compositions await detailed structural characterization of the water solution mechanisms in simple and complex magmatic melts.

\section{Silicate solubility in aqueous fluids}

In the schematic phase diagram in Figure 4, the boundaries silicate melt + aqueous fluid/aqueous fluid and silicate crystals + aqueous fluid/aqueous fluid define the silicate solubility in the fluid above and below the solidus of the system. The solubility of $\mathrm{SiO}_{2}$ in $\mathrm{H}_{2} \mathrm{O}$ has been the subject of more extensive experimental study than other chemically more complex silicates. From a compilation of available high-pressure/high-temperature solubility data, an effective way to describe solubility is in terms of temperature and the density of pure $\mathrm{H}_{2} \mathrm{O}$ at the temperature (and pressure) of interest (Manning 1994; see also Figure 7). It must be emphasized, however, that the empirical relationship used for this purpose,

$$
\begin{aligned}
\log \mathrm{m}_{\mathrm{SiO}_{2}}(\mathrm{~mol} / \mathrm{kg})= & 4.262-(5764.2 / \mathrm{T}(\mathrm{K}) \\
& +\left(1.7513 \bullet 10^{6} / \mathrm{T}^{2}\right) \\
& -\left(2.2868 \cdot 10^{8} / \mathrm{T}^{3}\right) \\
& +[2.8454-(1006.9 / \mathrm{T}) \\
& \left.+\left(3.5689 \cdot 10^{5} / \mathrm{T}^{2}\right)\right] \bullet \log \rho_{\mathrm{H}_{2} \mathrm{O}}
\end{aligned}
$$

uses the density of pure $\mathrm{H}_{2} \mathrm{O}$ to describe the silica solubility, and it is known that silicate components in
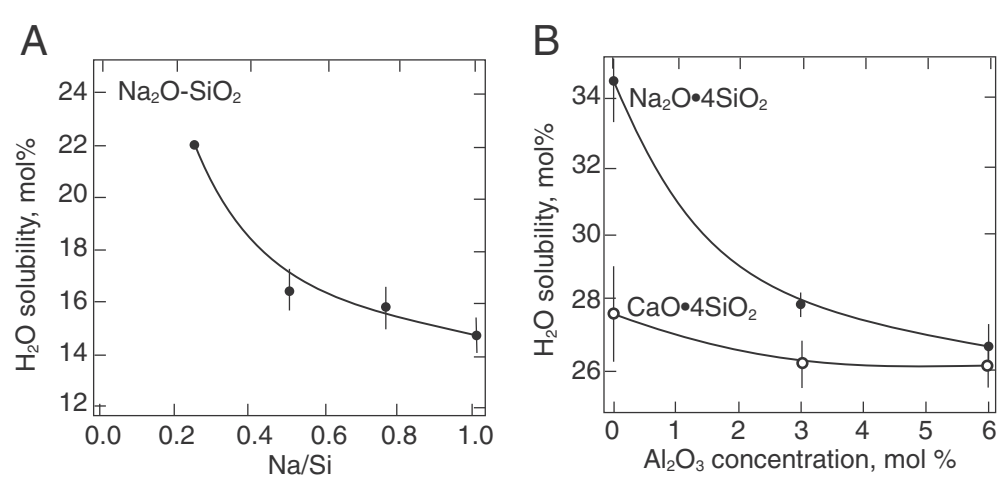

Figure $6 \mathbf{H}_{2} \mathrm{O}$ solubility in silicate and aluminosilicate melts with silicate composition. (A) Solubility at $1,200^{\circ} \mathrm{C}$ and $0.8 \mathrm{GPa}$ as a function of $\mathrm{Na} / \mathrm{Si}$ of the melt from Mysen (2002). (B) Solubility at $1,200^{\circ} \mathrm{C}$ and $2 \mathrm{GPa}$ as a function of $\mathrm{Al}_{2} \mathrm{O}_{3}$ content in $\mathrm{Na}_{2} \mathrm{O} \cdot 4 \mathrm{SiO}_{2}$ and $\mathrm{CaO} \cdot 4 \mathrm{SiO}_{2}$ melts as a function of added $\mathrm{Al}_{2} \mathrm{O}_{3}$ from Mysen and Wheeler (2000). 


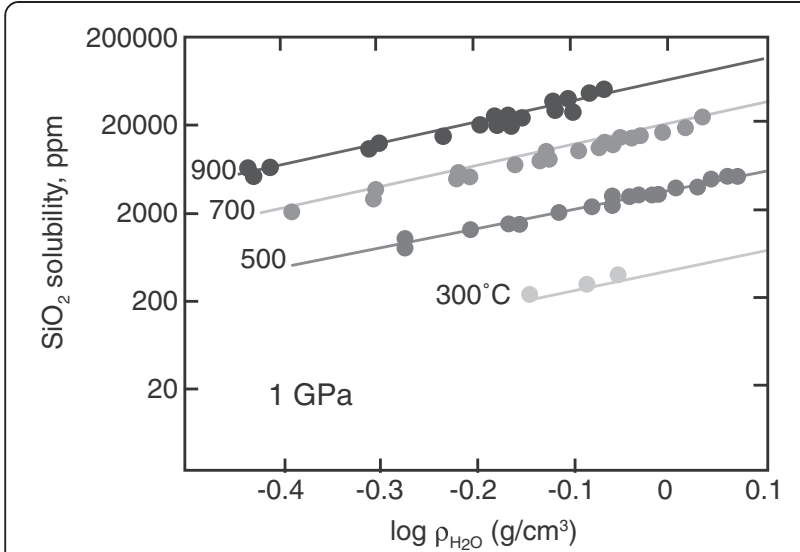

Figure 7 Silica solubility in fluid in equilibrium with quartz. As a function of the density of pure $\mathrm{H}_{2} \mathrm{O}$ at $1 \mathrm{GPa}$ and temperatures indicated calculated with the algorithm of Manning (1994) (Equation 1).

the solution affects the density of the solution (Mysen 2010a, b).

Additional components affect the silicate solubility in aqueous fluid. For example, addition of $\mathrm{MgO}$ to $\mathrm{SiO}_{2}$ reduces the $\mathrm{SiO}_{2}$ solubility (Zhang and Frantz 2000; Kawamoto et al. 2004; see also Figure 8). The $\mathrm{Mg} / \mathrm{Si}$ ratio of the fluid increases with pressure (Kawamoto et al. 2004). Below about $3 \mathrm{GPa}, \mathrm{MgO}$ cannot be detected in the fluid (Zhang and Frantz 2000; Kawamoto et al. 2004). The decreased $\mathrm{Mg} / \mathrm{Si}$ ratio of fluid with increasing pressure likely

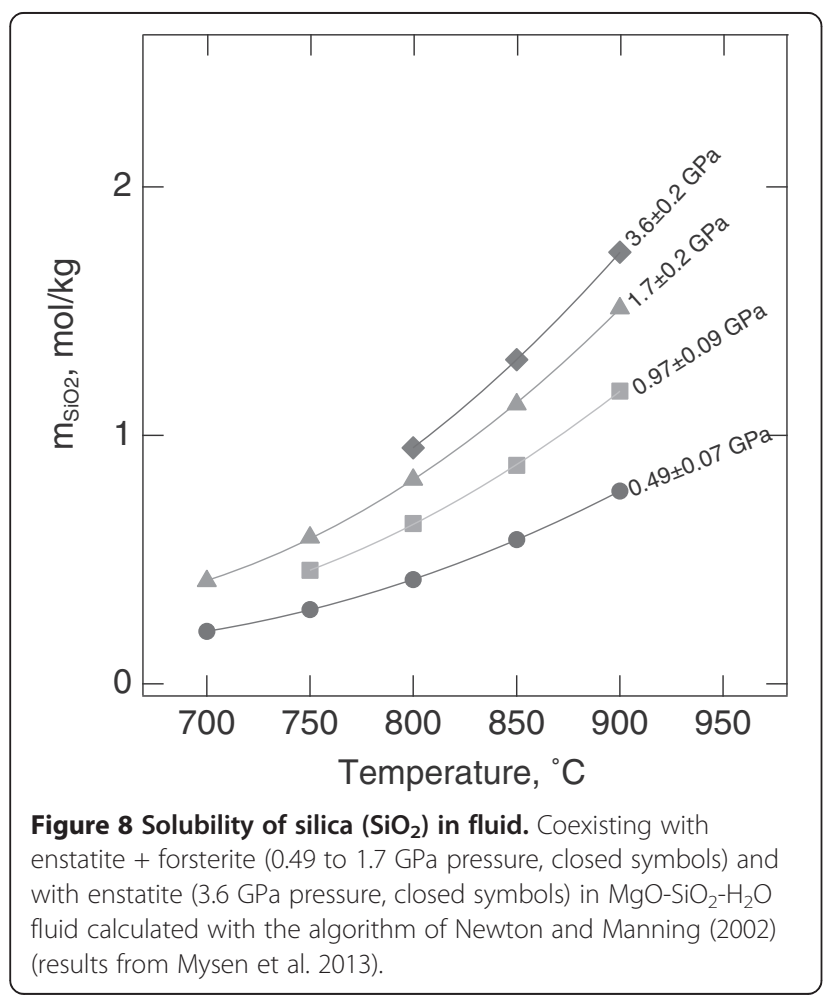

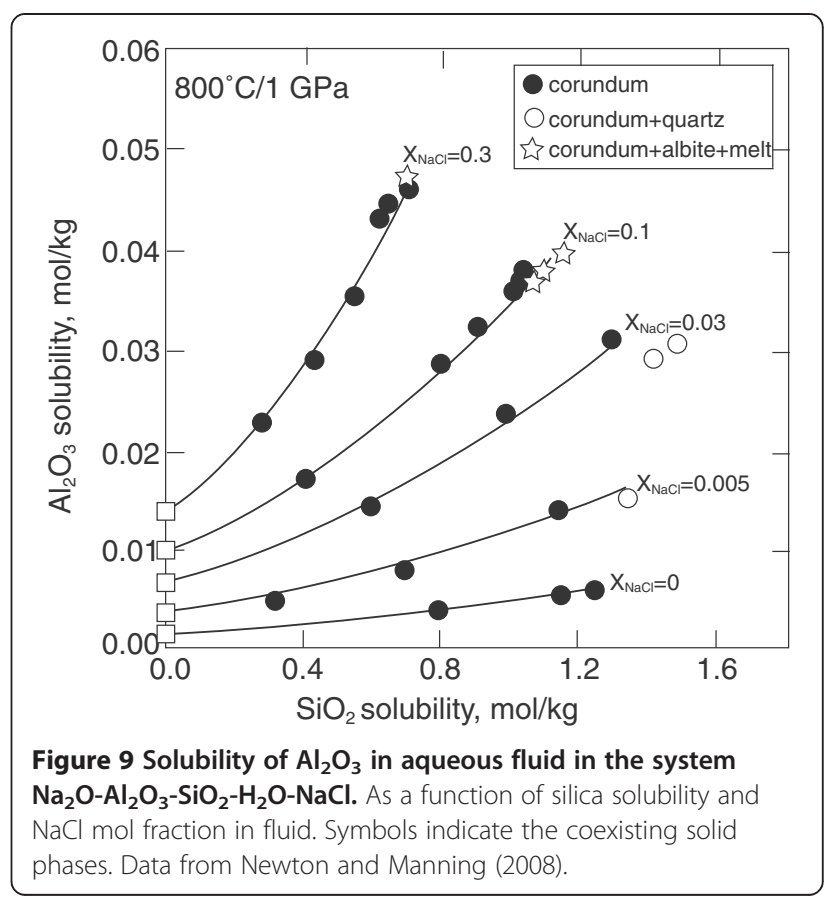

reflects the interaction between dissolved silica and $\mathrm{MgO}$ - perhaps similar to the solubility behavior of $\mathrm{Al}_{2} \mathrm{O}_{3}$ in fluids in the system $\mathrm{SiO}_{2}-\mathrm{Al}_{2} \mathrm{O}_{3}-\mathrm{H}_{2} \mathrm{O}-\mathrm{NaCl}$ where increasing $\mathrm{SiO}_{2}$ content in the fluid enhances the $\mathrm{Al}_{2} \mathrm{O}_{3}$ solubility (Figure 9). In the latter system, there is also a pronounced positive effect of increasing $\mathrm{NaCl}$ in the fluid (Newton and Manning 2008).

Oxides that are essentially insoluble in pure $\mathrm{H}_{2} \mathrm{O}$ also can be affected quite strongly by other solutes such as silicate and aluminosilicate components. As an example, the solubility if $\mathrm{Ti}^{4+}$ in fluid in equilibrium with melt in the $\mathrm{Na}_{2} \mathrm{O}-\mathrm{Al}_{2} \mathrm{O}_{3}-\mathrm{SiO}_{2}-\mathrm{TiO}_{2}-\mathrm{H}_{2} \mathrm{O}$ is a strong positive function of concentration of aluminosilicate component in addition to temperature and pressure (Antignano and Manning 2008; Mysen 2012a; see Figure 10). This is a very different solution behavior than that of $\mathrm{TiO}_{2}$ in the simple system, $\mathrm{TiO}_{2}-\mathrm{H}_{2} \mathrm{O}$; here, the $\mathrm{Ti}$ solubility is in the parts per million range (Audetat and Keppler 2005; Antignano and Manning 2008). Similar effects have been observed for $\mathrm{P}^{5+}$ and other high field strength cations (Mysen 2011; Bernini et al. 2013). It follows, therefore, that during dehydration of subducting slabs where the fluid is quite silicate rich, it will likely carry significantly greater proportions of nominally refractory oxides than that expected from solubility measurements with pure $\mathrm{H}_{2} \mathrm{O}$ as the solute (see also Manning 2004).

\section{Melt and glass}

\section{Glass transition}

Most of the experimental data on solubility and solution behavior of water in silicate melts at high temperature 


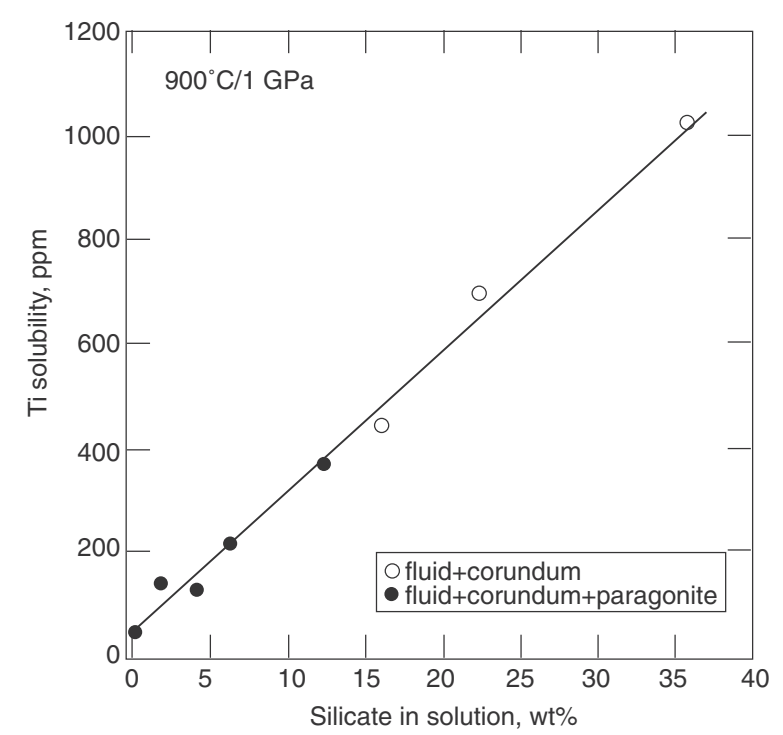

Figure $10 \mathrm{TiO}_{2}$ solubility in fluids in equilibrium. With rutile in the system $\mathrm{TiO}_{2}$-Al-silicate ( $\mathrm{NaAlSi}_{3} \mathrm{O}_{8}$ starting composition) as a function of $\mathrm{SiO}_{2}$ in solution. Data from Antignano and Manning (2008).

have been obtained by analysis of the glass formed by temperature quenching from a high-temperature/highpressure hydrous melt. Temperature-dependent structure may change during such a cooling process and eventually gets frozen in at the temperature of the glass transition (Dingwell and Webb 1990). By definition, the glass transition temperature (actually a small temperature range), therefore, is that below which the material is not relaxed on the time scale of a measurement (glass), whereas above that temperature, the material is relaxed (liquid). In the temperature interval between a liquidus and glass transition temperature, the material is a supercooled liquid with the same property behavior as that of the melt above the melting temperature. These distinctions are important when a property measured on a glass is applied to the property behavior of its melt.

\section{Principles of silicate melt structure}

Characterization of water solution mechanisms in silicate melts, including magmatic melts, requires understanding of the principles of silicate melt structure. A basic structure concept is a degree of polymerization of the silicate network of oxygen tetrahedra with their centrally located tetrahedrally coordinated cation (T-cation) (Figure 11). The dominant T-cations in magmatic melts and glasses are $\mathrm{Si}^{4+}$ and $\mathrm{Al}^{3+}$ provided that the pressure is less than that where these cations may undergo coordination transformations (coordination transformations begin to take place $\geq 5$ to $6 \mathrm{GPa}$ depending on whether it is $\mathrm{Al}^{3+}$ or $\mathrm{Si}^{4+}$ and depending on the overall melt

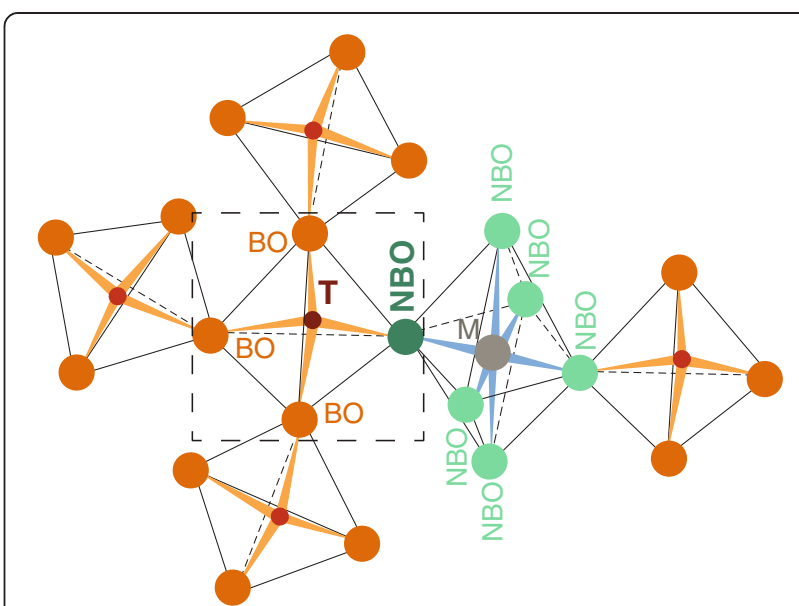

Figure 11 Schematic representation of the concept of bridging (BO) and nonbridging (NBO) oxygen.

composition; see, for example, Ohtani et al. 1985; Lee et al. 2004). There are two types of oxygen forming the corners of these tetrahedra. An oxygen shared by neighboring tetrahedra is termed a bridging oxygen (BO), and the one shared between a tetrahedron and a neighboring polyhedron that does not form tetrahedral network is termed nonbridging oxygen (NBO) (see Figure 11).

The degree of melt polymerization is defined as the proportion of nonbridging oxygen per tetrahedrally coordinated cations, NBO/T. The NBO/T of a silicate melt and glass can be calculated from its bulk composition provided that the type and proportion of T-cations are known. This can be done by keeping in mind that electrical neutrality requires $\mathrm{T}$-cations to be assigned a formal charge of $4+$ and oxygen $2-$ so that

$$
\mathrm{NBO} / \mathrm{T}=\left(4 \bullet \mathrm{X}_{\mathrm{T}}-2 \cdot \mathrm{X}_{\mathrm{O}}\right) / \mathrm{X}_{\mathrm{T}},
$$

where $\mathrm{X}_{\mathrm{T}}$ and $\mathrm{X}_{\mathrm{O}}$ are the atomic proportions of tetrahedrally coordinated cations and oxygen, respectively.

The distribution of NBO/T of major rock-forming magmatic melts suggests a general correlation between aluminosilicate concentration in the magma and their degree of polymerization, NBO/T (Figure 12). The NBO/T of common magmatic melts is the 0 to 1 range (Figure 12). It is for this reason that most studies of simple system melt structure have focused on melt compositions in this NBO/ $\mathrm{T}$ range.

Silicate glasses and melts, including those of natural magma and many commercial glasses, can be described in terms of a small number of discrete silicate polymers with integer values for their average $\mathrm{NBO}$ and $\mathrm{BO}(\mathrm{BO}=4-$ NBO) between 0 and 4 (Virgo et al. 1980; Stebbins 1987; Maekawa et al. 1991; Buckermann et al. 1992). These entities sometimes have been described in terms of their silicate stoichiometries $\left(\mathrm{TO}_{4}, \mathrm{~T}_{2} \mathrm{O}_{7}, \mathrm{TO}_{3}, \mathrm{~T}_{2} \mathrm{O}_{5}\right.$, and $\left.\mathrm{TO}_{2}\right)$ 


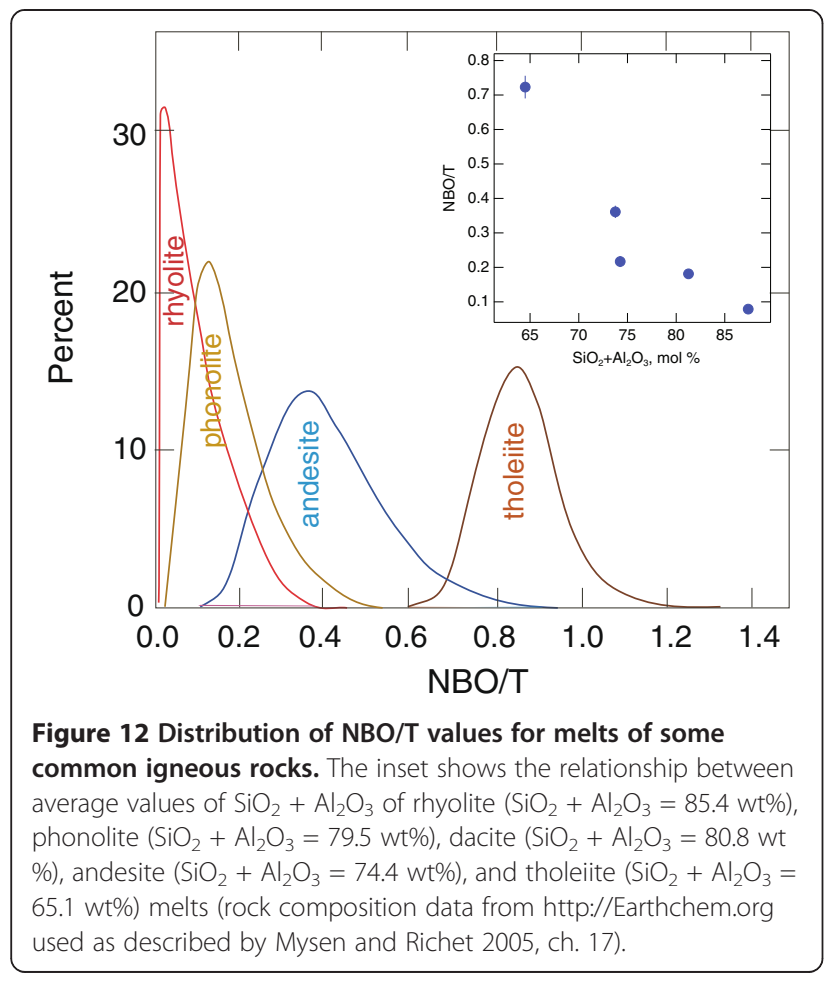

and sometimes by using the $Q^{n}$ species notation, $Q^{0}, Q^{1}$, $Q^{2}, Q^{3}$, and $Q^{4}$, where the superscript indicates the number of BO. Consequently, $Q^{0}=\mathrm{TO}_{4}, Q^{1}=0.5 \mathrm{~T}_{2} \mathrm{O}_{7}, Q^{2}=$ $\mathrm{TO}_{3}, Q^{3}=0.5 \mathrm{~T}_{2} \mathrm{O}_{5}$, and $Q^{4}=\mathrm{TO}_{2}$. The proportion of these species, but not their stoichiometry, varies as a function of melt composition (metal oxide/Si and $\mathrm{Si} / \mathrm{Al}$ ratios). For any melt composition, its degree of polymerization, $\mathrm{NBO} / \mathrm{T}$, can be calculated from the proportion of the $Q^{n}$ species:

$$
N B O / T=\sum_{n=0}^{n=4}(4-n) \cdot X_{Q^{n}}
$$

where $n$ is the number of bridging oxygen and $X_{Q^{n}}$ mol fraction of individual $Q^{n}$ species. However, $Q^{n}$ species abundance obviously cannot be calculated from $\mathrm{NBO} / \mathrm{T}$ values alone.

\section{Solution mechanisms of silicate and water in fluids and melts in hydrous magmatic systems}

Most structural data from hydrous silicate melts have been obtained from analysis of samples quenched from high temperature and pressure to ambient conditions prior to chemical and structural analysis. These data reflect, therefore, the melt structural environment near the glass transition temperature. Temperature-dependent structural features cannot be captured in such studies. That notwithstanding, many important principles have been derived from studies of quenched melt.
The behavior of an aqueous fluid in equilibrium with molten or crystalline silicates at high temperature and pressure may not be addressed by examination of quenched materials because most, perhaps all, of their properties (including the structure itself) cannot be determined by examination of the high-temperature/high-pressure fluid after quenching to ambient conditions. Fluid structure studies require, therefore, examination while the sample is at the temperature and pressure of interest. However, before addressing such experimental environments, structural data from quenched melts will be discussed.

\section{Hydrous melts quenched from high temperature at high pressure}

Water is dissolved in silicate melts in the form of water molecules, $\mathrm{H}_{2} \mathrm{O}^{0}$, and structurally bound hydroxyl groups, $\mathrm{OH}$. The $\mathrm{OH}$ groups can form bonds with $\mathrm{Si}^{4+}$ and $\mathrm{Al}^{3+}$ as well as with other metal cations (Mysen and Virgo 1986; Xue and Kanzaki 2004; Cody et al. 2005). In either case, water dissolved in the form of $\mathrm{OH}$ groups in silicate melts affects their structure.

In the simplest of silicates, $\mathrm{SiO}_{2}$, the $\mathrm{OH}$ formation is via breakage of bridging oxygen bonds (Wasserburg 1957; Farnan et al. 1987):

$$
\mathrm{Si}-\mathrm{O}-\mathrm{Si}+\mathrm{H}_{2} \mathrm{O}=2 \mathrm{Si}-\mathrm{OH},
$$

where $\mathrm{Si}-\mathrm{O}-\mathrm{Si}$ represents an oxygen bridge and $\mathrm{Si}-\mathrm{OH}$ a broken bridge terminated with $\mathrm{H}^{+}$. Formulated in terms of $Q^{n}$ species and supported by ${ }^{29} \mathrm{Si}$ and ${ }^{1} \mathrm{H}^{-29} \mathrm{Si} \mathrm{CP}$ MAS NMR (cross-polarization magic angle spinning nuclear magnetic resonance) data for $\mathrm{SiO}_{2}-\mathrm{H}_{2} \mathrm{O}$ (Farnan et al. 1987; Cody et al. 2005), this reaction can be written as

$$
2 \mathrm{Q}^{4}+\mathrm{nH}_{2} \mathrm{O}=2 \mathrm{Q}^{4-\mathrm{n}}(\mathrm{H}),
$$

In chemically more complex systems, the $\mathrm{OH}$-forming process also is more complex as will be discussed further below.

From the experimental studies of temperature-quenched hydrous glasses, the proportion, $X_{\mathrm{OH}} / X_{\mathrm{H}_{2} \mathrm{O}^{0}}$, varies with total water concentration and with bulk chemical composition of the melt (Stolper 1982; Dixon and Stolper 1995; Zotov and Keppler 1998; see also Figure 13). Above the glass transition temperature, the $X_{\mathrm{OH}} / X_{\mathrm{H}_{2} \mathrm{O}^{0}}$ is positively correlated with temperature so that a simple water speciation reaction,

$$
\mathrm{H}_{2} \mathrm{O}^{0}+\mathrm{O}^{2-}=2 \mathrm{OH}^{-}
$$

shifts to the right with temperature (Nowak and Behrens 1995; see also Figure 13B). From the temperaturedependent equilibrium, an enthalpy change, $\Delta H$, of about $30 \mathrm{~kJ} / \mathrm{mol}$ has often been reported (Nowak and Behrens 1995). 

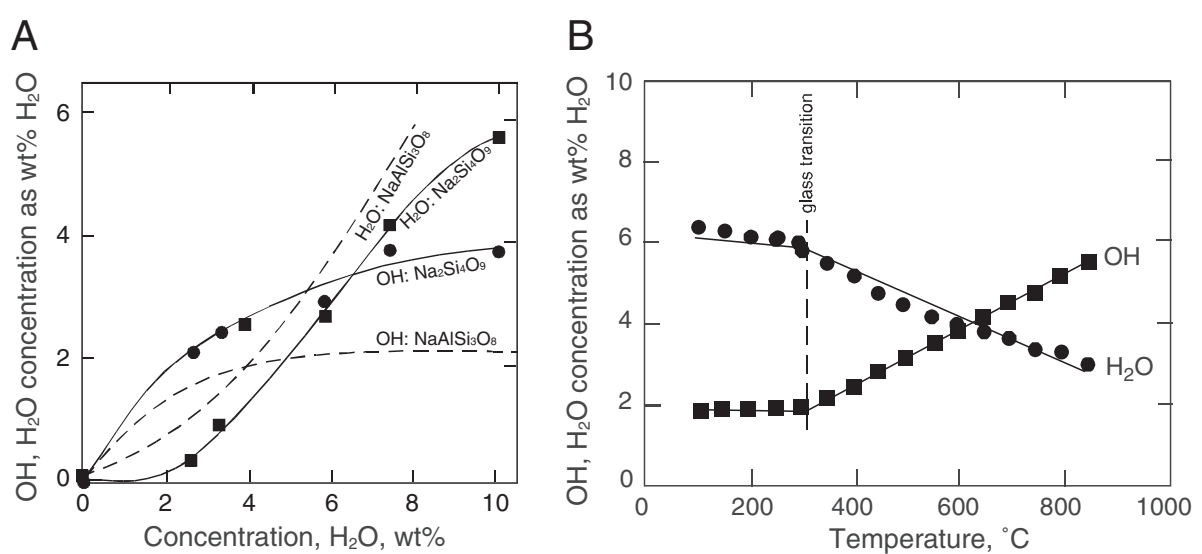

Figure 13 Abundance of $\mathrm{OH}$ groups and molecular $\mathrm{H}_{2} \mathrm{O}$ as a function of water concentration and temperature. (A) Evolution of abundance of $\mathrm{OH}$ groups and molecular $\mathrm{H}_{2} \mathrm{O}$ as a function of total water concentration in quenched melts (quenched from $1,100^{\circ} \mathrm{C}$ at $200 \mathrm{MPa}$ pressure) of compositions indicated (data from Zotov and Keppler 1998). (B) Abundance of $\mathrm{OH}$ groups and molecular $\mathrm{H}_{2} \mathrm{O}$ in haplogranite composition glass and melt as a function of temperature from Nowak and Behrens (1995) recorded in situ while the sample was at the temperature of interest as shown with the pressure constant at $150 \mathrm{MPa}$.

Data such as those in Figure 13 do not provide information about how the $\mathrm{OH}$ groups form bonding with the silicate melt structure. In the simple form of Equation 4 whereby $\mathrm{Si}-\mathrm{OH}$ bonding is formed, there is depolymerization of the melt ( $\mathrm{NBO} / \mathrm{T}$ increases). By adding one or more alkali metal or alkaline earth to $\mathrm{SiO}_{2}$, bridging oxygen bond breakage also takes place and an increase in NBO/Si as water is dissolved. The rate of $\mathrm{NBO} / \mathrm{Si}$ change at constant total water concentration decreases with increasing metal oxide/silicon ratio $(\mathrm{Na} / \mathrm{Si}$ in the case of the data in Figure 14; see also Cody et al. 2005). The rate of change also decreases with increasing total water content (Figure 15).

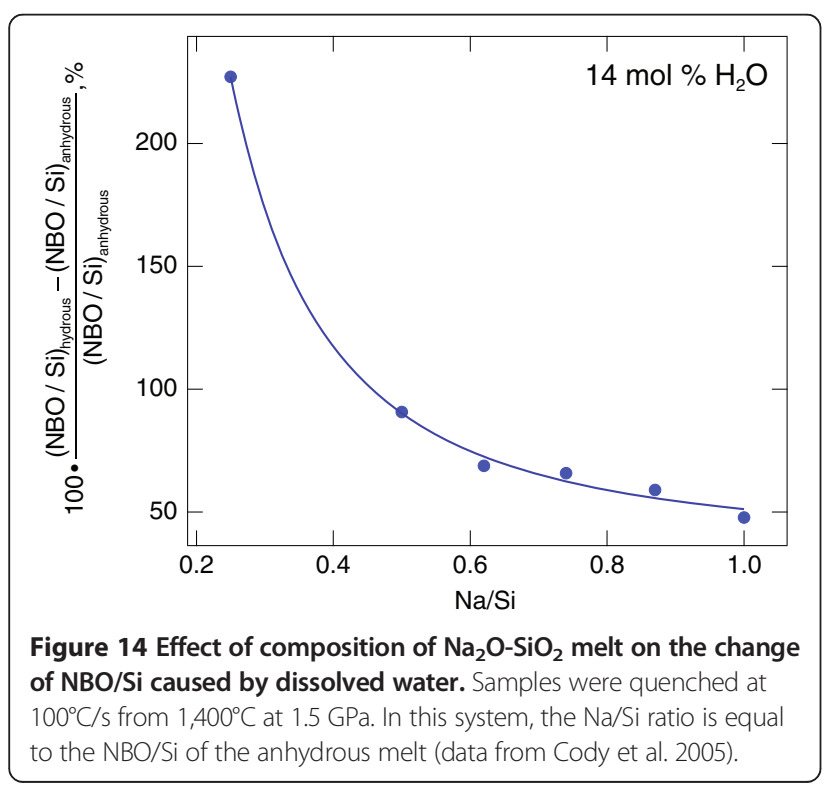

The NBO/Si decrease caused by increasing metal/ silicon ratio (Figure 14) could occur either because the $X_{\mathrm{OH}} / X_{\mathrm{H}_{2} \mathrm{O}^{0}}$ decreases with increasing metal/Si or it is because some of the $\mathrm{OH}$ groups form bonding with a network-modifying metal cation instead of breaking oxygen bridges to form $\mathrm{Si}-\mathrm{OH}$ bonds. A simple example is what might be expected in an $\mathrm{Na}_{2} \mathrm{O}-\mathrm{SiO}_{2}$ melt, where $\mathrm{Na}^{+}$ in the anhydrous melt forms bonding with nonbridging oxygen. Here, in addition to a reaction such as shown schematically in Equation 4, a structural interaction with $\mathrm{Na}^{+}$can be written as

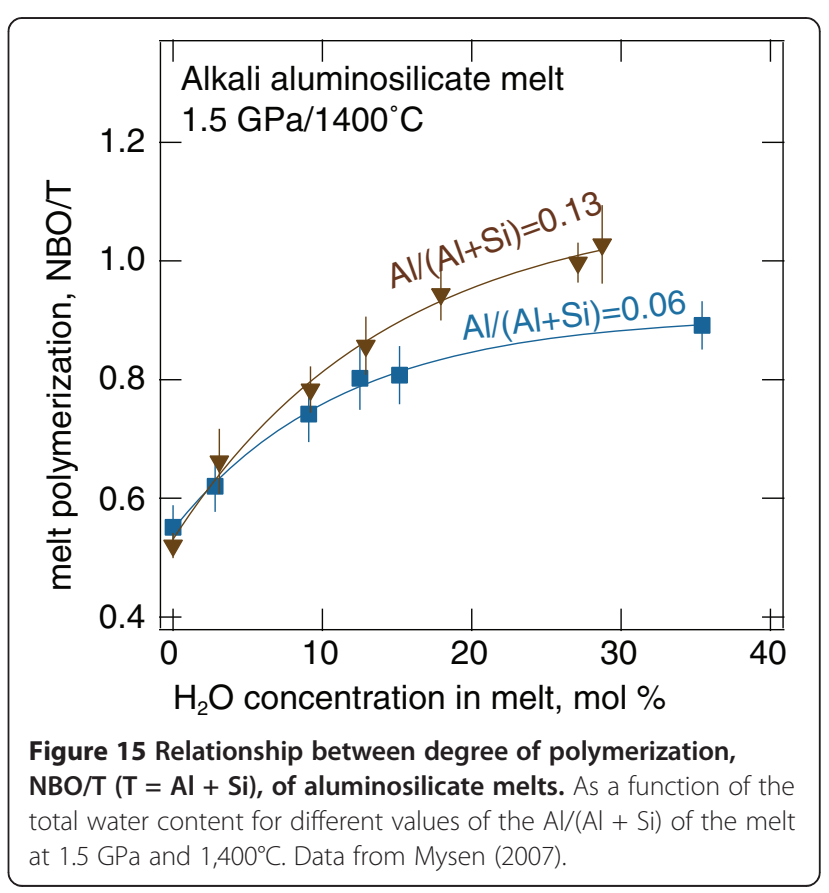




$$
2 \mathrm{Q}^{3}(\mathrm{Na})+\mathrm{H}_{2} \mathrm{O}=\mathrm{Q}^{4}+2 \mathrm{NaOH} .
$$

In this example, the network-modifying $\mathrm{Na}^{+}$bonding with nonbridging oxygen in a $Q^{3}$ species (with $\mathrm{NBO} / \mathrm{Si}=1$ ) in an anhydrous melt reacts with $\mathrm{H}_{2} \mathrm{O}$ to form $\mathrm{NaOH}$ complexes in hydrous $\mathrm{Na}_{2} \mathrm{O}-\mathrm{SiO}_{2}$ melts. This interaction causes the nonbridging oxygens bonded to $\mathrm{Na}^{+}$in anhydrous $Q^{3}$ to be transformed to bridging oxygens resulting in the formation of the more polymerized $Q^{4}$ species. Silicon-29 MAS NMR data from melts quenched from $1,400^{\circ} \mathrm{C}$ along the $\mathrm{Na}_{2} \mathrm{O}-\mathrm{SiO}_{2}$ join show that this is exactly the situation and that the abundance of $\mathrm{NaOH}$ complexes increases with increasing $\mathrm{Na} / \mathrm{Si}$ (Cody et al. 2005). Similar conclusions have been reported for alkaline earth silicate glasses wherein $\mathrm{Ca} . . \mathrm{OH}$ and $\mathrm{Mg}$...H groups were formed in $\mathrm{CaO}-\mathrm{MgO}-\mathrm{SiO}_{2}$ melts (Xue and Kanzaki 2004).

From a compositional perspective, aluminosilicate melts are more akin to natural magmatic melts than metal oxide silicate melts. At pressures less than 5 to $6 \mathrm{GPa}, \mathrm{Al}^{3+}$ is in tetrahedral coordination where it is charge-balanced with alkalis or alkaline earths in a manner conceptually similar to that observed in crystalline aluminosilicates such as feldspars (see Lee et al. 2004; for high-pressure structural data). The aluminate groups $\left(\mathrm{AlO}_{2}^{-}\right)$in aluminosilicate melts can interact with dissolved water to form either $\mathrm{Al}$ $\mathrm{OH}$ or metal-OH bonding (metal can be alkali metal or alkaline earth), or both, in addition to $\mathrm{Si}-\mathrm{OH}$ bonding (Mysen and Virgo 1986; Schmidt et al. 2001). The extent to which aluminate interaction takes place is correlated with the Si/Al ratio of the melt (Mysen and Virgo 1986). The nature of the $\mathrm{Al}^{3+}$ charge balance probably also affects the solution mechanism because the Al-O bond strength depends on the electronic properties of the charge-balancing cation (Roy and Navrotsky 1984).

The formation of Al-OH bonding can be illustrated schematically by using aluminate complexes, denoted as $\mathrm{M}^{m+}{ }_{1 / m} \mathrm{Al}_{m} \mathrm{O}_{2 m}$, to describe the silicate speciation, and $\mathrm{Al}(\mathrm{OH})_{3}$ as a representation of $\mathrm{Al}-\mathrm{OH}$ formation in the melt:

$$
\begin{aligned}
2 M_{1 / m}^{m+} A l_{m} \mathrm{O}_{2 m} & +{ }^{3} /{ }_{m} \mathrm{H}_{2} \mathrm{O}+2 Q^{n} \rightleftharpoons 2 /{ }_{m} \mathrm{Al}(\mathrm{OH})_{3} \\
& +2 Q^{n-1}\left(1 / m M^{m+}\right),
\end{aligned}
$$

Additional complexity may exist because in melts with mixed $\mathrm{M}^{m+}$ cations and $\mathrm{H}^{+}$, the $\mathrm{H}^{+}$, because of its size for steric reasons, exhibits preference for forming $\mathrm{OH}$ groups in the silicate portion of the network by reacting with the nonbridging oxygen in $Q^{n}$ species with the largest number of nonbridging oxygens (Cody et al. 2005).

Transformation of tetrahedrally coordinated $\mathrm{Al}^{3+} \mathrm{OH}-$ bearing complexes, therefore, results in silicate depolymerization wherein the rate of depolymerization with $\mathrm{H}_{2} \mathrm{O}$ increases the more aluminous the melt (Figure 15). This

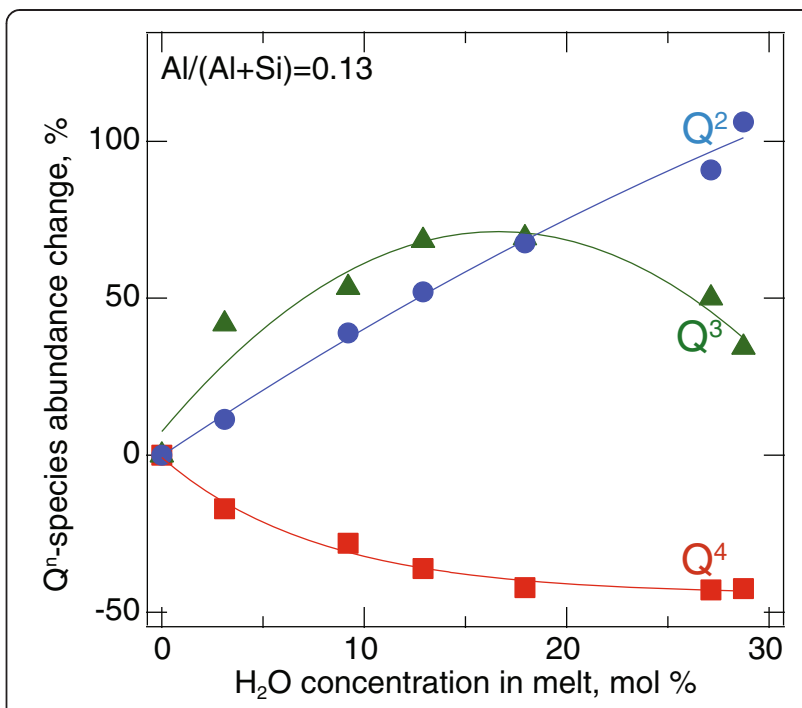

Figure 16 Evolution of $Q^{n}$ species abundance. In quenched (at $100^{\circ} \mathrm{C} / \mathrm{s}$ from $1,400^{\circ} \mathrm{C}$ at $1.5 \mathrm{GPa}$ ) hydrous Na-aluminosilicate melts as a function of $\mathrm{H}_{2} \mathrm{O}$ content at fixed $\mathrm{Al} /(\mathrm{Al}+\mathrm{Si}$ ) (data from Mysen 2007)

depolymerization (increasing $\mathrm{NBO} / \mathrm{T}$ ) takes place because as the tetrahedrally coordinated $\mathrm{Al}^{3+}$ interacts with $\mathrm{H}_{2} \mathrm{O}$ to form $\mathrm{Al}-\mathrm{OH}$ bonds, an equivalent proportion of the charge-balancing cation becomes a network-modifier, or charge-balancing $\mathrm{Na}^{+}$for $\mathrm{Na}-\mathrm{OH}$ bonds leading to network-modifying $\mathrm{Al}^{3+}$, or both. This depolymerization is also reflected in water concentration-dependent $Q^{n}$ abundance as a function of total water content (Figure 16) where the abundance of individual $Q^{n}$ species at a given total water content also varies with the $\mathrm{Al} /(\mathrm{Al}+\mathrm{Si})$ of the melt (Mysen 2007). The example from the $\mathrm{Na}_{2} \mathrm{O}-\mathrm{Al}_{2} \mathrm{O}_{3}$ $\mathrm{SiO}_{2}-\mathrm{H}_{2} \mathrm{O}$ system shows how depolymerized species, $Q^{3}$ and $Q^{2}$, become more important as more polymerized species, $Q^{4}$, abundance decreases (Figure 16).

The decreasing $\partial(\mathrm{NBO} / \mathrm{T}) / \partial X_{\mathrm{H}_{2} \mathrm{O}}$ with increasing water content, $X_{\mathrm{H}_{2} \mathrm{O}}$, reflects the decreasing rate of change of the abundance ratio, $X_{\mathrm{OH}} / X_{\mathrm{H}_{2} \mathrm{O}^{0}}$, as the total water content increases. This evolution, in turn, reflects the diminishing rate by which the $Q^{n}$ species changes with increasing concentration of water in the melt (Figure 16). These composition-dependent solution mechanisms of water in aluminosilicate melts also explain why the solubility of water in silicate melt at any temperature and pressure is significantly dependent on the bulk chemical composition of the melt itself.

\section{Hydrous melts and aqueous fluids at high temperature and pressure}

Experimental protocols have recently been implemented for examination of fluids and melts in hydrous silicate systems at deep crustal and mantle pressures and temperatures in situ while the sample is at the desired 
pressure and temperature conditions. Structural data obtained under such conditions are, therefore, increasingly available from all regions of silicate- $\mathrm{H}_{2} \mathrm{O}$ phase diagrams (Figure 4). In considering such data, commonly obtained in so-called hydrothermal diamond anvil cells (e.g., Bassett et al. 1994), the experiments usually are conducted in such a manner that pressure is a variable dependent on temperature. This means that increasing temperature normally is associated with increasing pressure. In the following discussion, this is the case unless otherwise indicated.

High-temperature/high-pressure in situ examination of hydrous silicate systems includes characterization of pure $\mathrm{H}_{2} \mathrm{O}$, characterization of the silicate components, and mixtures between the two. For the $\mathrm{H}_{2} \mathrm{O}$ component itself, the diminishing extent of hydrogen bonding with temperature is the only structure observable. There are, however, differences between hydrogen bonding of water dissolved in melts (typically supercooled liquids), of silicate-saturated aqueous fluid, and pure $\mathrm{H}_{2} \mathrm{O}$. The $\Delta H$ for hydrogen bond formation in such melts is near 10 and about $22 \mathrm{~kJ} / \mathrm{mol}$ for silicate-saturated aqueous fluid (Figure 17). The $\Delta H$ for pure $\mathrm{H}_{2} \mathrm{O}$ is slightly above $25 \mathrm{~kJ} / \mathrm{mol}$ (Walrafen et al. 1986). Hydrogen bonding cannot be detected spectroscopically at temperatures above $500^{\circ} \mathrm{C}$ to $550^{\circ} \mathrm{C}$ (Foustoukos and Mysen 2012; Mysen 2013).

In hydrous silicate systems, the ratio of mol fraction of water species, $X_{\mathrm{OH}} / X_{\mathrm{H}_{2} \mathrm{O}^{0}}$, in fluid, melt, and supercritical fluid varies with temperature (Mysen 2010b; see also Figure 18). The $X_{\mathrm{OH}} / X_{\mathrm{H}_{2} \mathrm{O}^{0}}$ ratio of water in fluid and

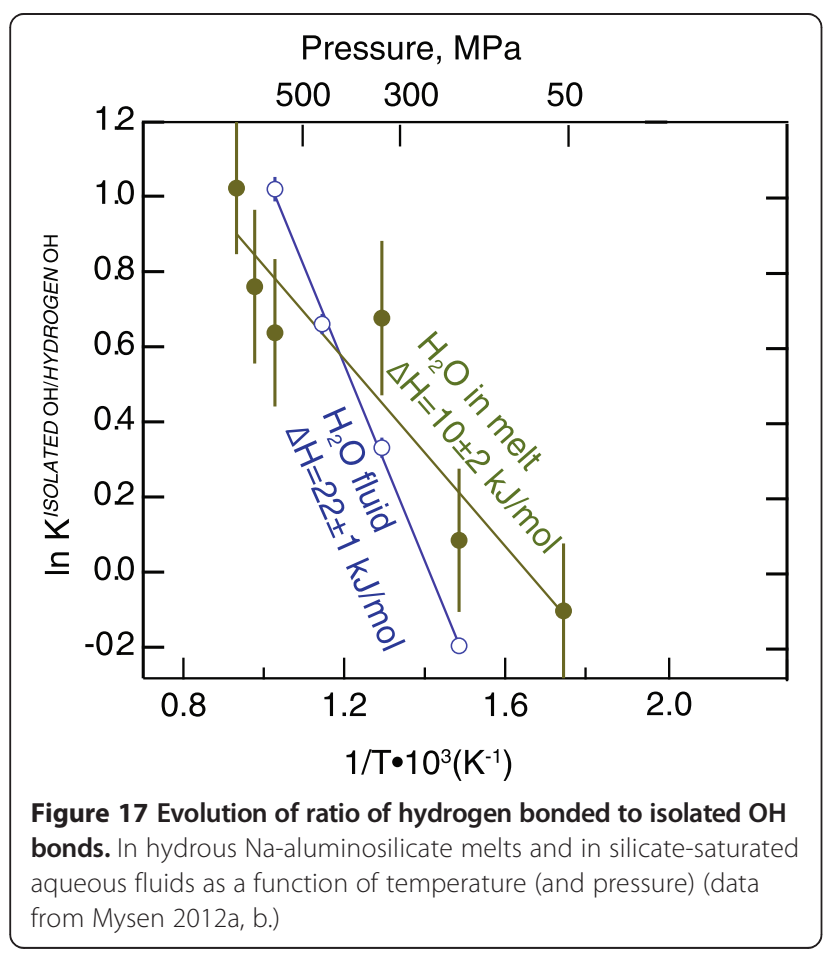

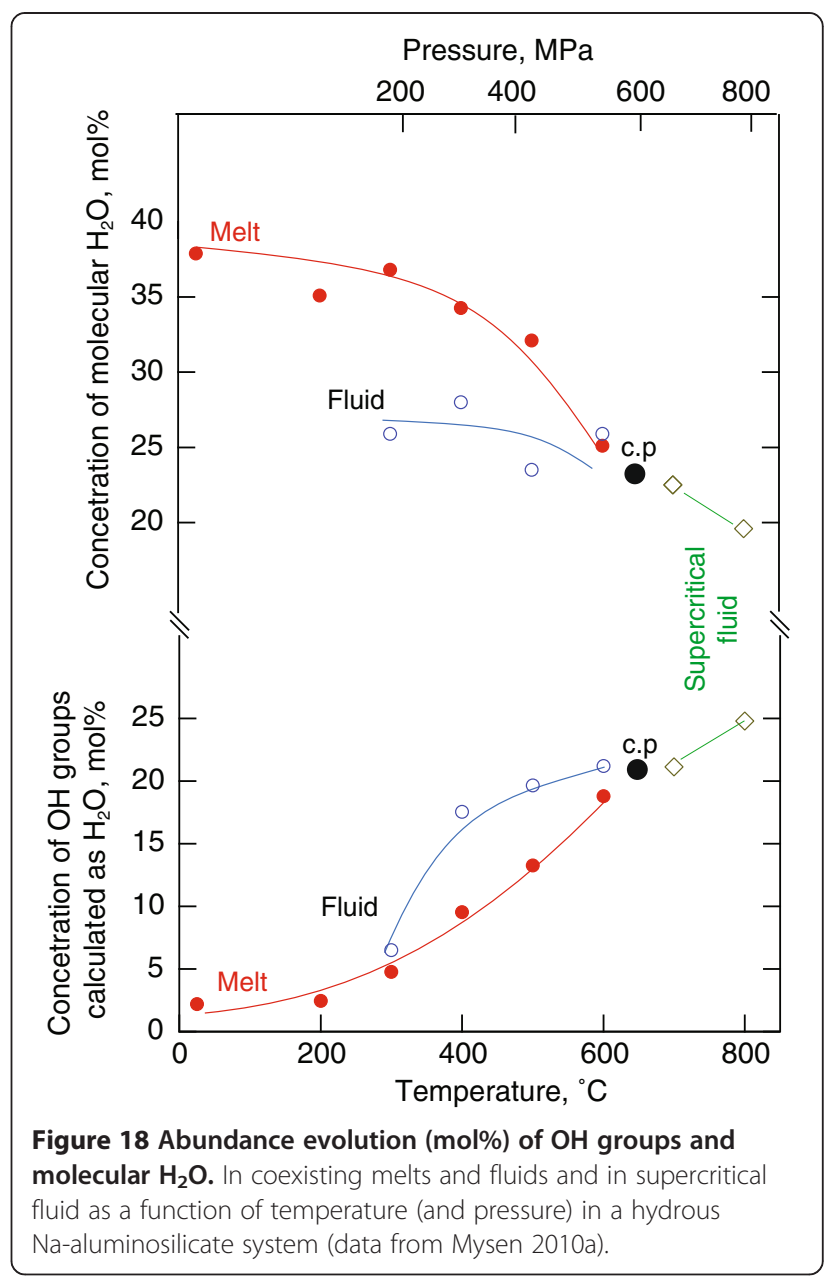

melt converges at the second c.p. (Figure 18). The existence of $\mathrm{OH}$ groups in all three phases (melt, fluid, supercritical fluid) implies structural interaction between water and silicate components. In fact, structural data obtained from vibrational spectroscopy indicate that in any silicate systems, the types of $Q^{n}$ species in fluids, melts, and supercritical fluids resemble one another (Mysen 2009) although their concentration at any temperature and pressure depends on the silicate composition and whether in fluids or melts. The latter differences are evident in the NBO/T of the silicate melt being considerably lower (the melt is more polymerized) than coexisting fluid (Figure 19). The NBO/T values approach each other with increasing temperature and pressure until they merge at c.p. Interestingly, at higher temperature and pressure above those that define the c.p., the silicate in supercritical aqueous fluids becomes further depolymerized (NBO/T increases) (see Figure 19).

The NBO/T variations illustrated in Figure 19 reflect temperature- and pressure-dependent $Q^{n}$ species in fluids and melts. Their partition coefficients, $K_{\mathrm{Qn}}$ fluid/melt, at any temperature and pressure are sensitive functions 


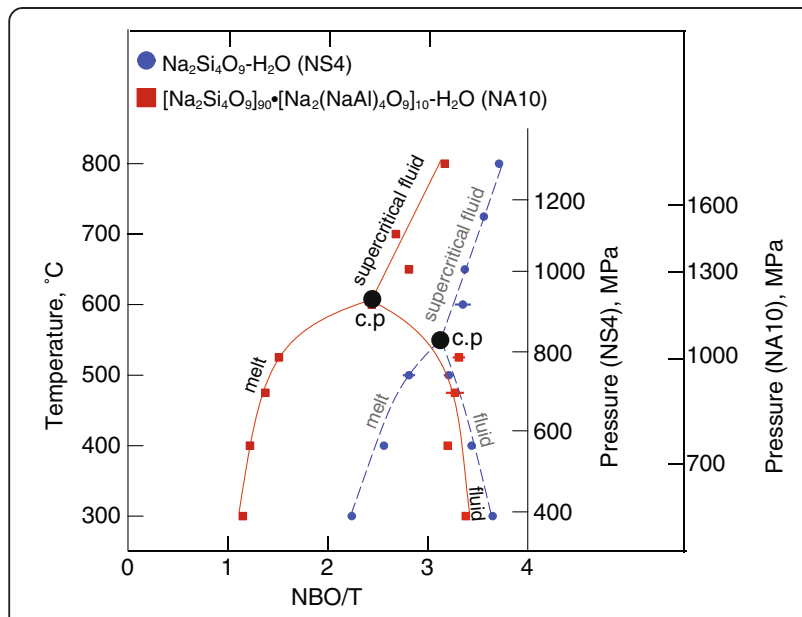

Figure 19 Degree of silicate polymerization, NBO/T. In silicate in hydrous melts, silicate-saturated aqueous fluid, and supercritical fluid in a hydrous Na-aluminosilicate system (data from Mysen 2012a, b)

of the degree of polymerization of the species (Figure 20). The $K_{\mathrm{Qn}}$ fluid/melt of the least polymerized $Q^{n}$ species is the largest and then decreases systematically as the $n$ value increases. Moreover, this effect becomes increasingly pronounced as the temperature and pressure decreases. The latter effect results from two factors. First, the aluminosilicate solubility in aqueous fluid decreases with decreasing pressure and temperature. The lowered silicate concentration leads to increasing abundance of less polymerized $Q^{n}$ species in the fluid (Mysen 2010a). Second, the extent to which the silicate species in the hydrous melts are affected by dissolved water is a positive function of water content (Figure 16) and water solubility decreases with decreasing pressure (and temperature).

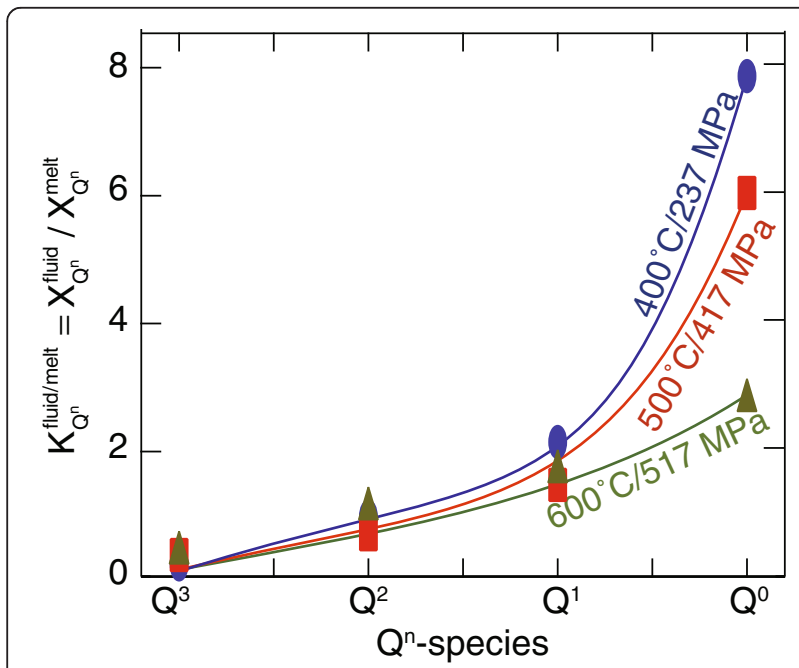

Figure $20 Q^{n}$ species partitioning between coexisting fluid and melt. As a function of type of $Q^{n}$ species, temperature, and pressure in a hydrous Na-aluminosilicate system (data from Mysen 2012a, b).
Both effects would cause the $K_{\mathrm{Qn}}^{\text {fluid/melt }}$ partition coefficients to increase.

In the compositionally simple silica- $\mathrm{H}_{2} \mathrm{O}$ system in the $400^{\circ} \mathrm{C}$ to $900^{\circ} \mathrm{C}$ temperature range at pressures at and below about 1.4 GPa, only $Q^{0}$ and $Q^{1}$ species in the fluid can be detected. The equilibrium constant for the polymerization equilibrium in fluids is

$$
K=X_{\mathrm{Q} 1} / X_{\mathrm{Qo}},
$$

with $\Delta \mathrm{H}=13.3 \pm 1.5 \mathrm{~kJ} / \mathrm{mol}$ (Mysen 2010b) if it is assumed that $\Delta V=0$ for this equilibrium, and, therefore, that the increasing pressure governed by increasing temperature does not affect the equilibrium. However, the partial molar volume of $Q^{0}$ species is smaller than that of $Q^{1}$ species (Bottinga and Richet 1995) so that with the likelihood of $\Delta V>0$, the $\Delta \mathrm{H}=13.3 \mathrm{~kJ} / \mathrm{mol}$ is a minimum value. At higher pressures $(\geq 1.8 \pm 0.2 \mathrm{GPa}$; see Mysen et al. 2013), the positive pressure- and temperature-dependent total silica concentration in fluid leads to further polymerization of the silicate species,

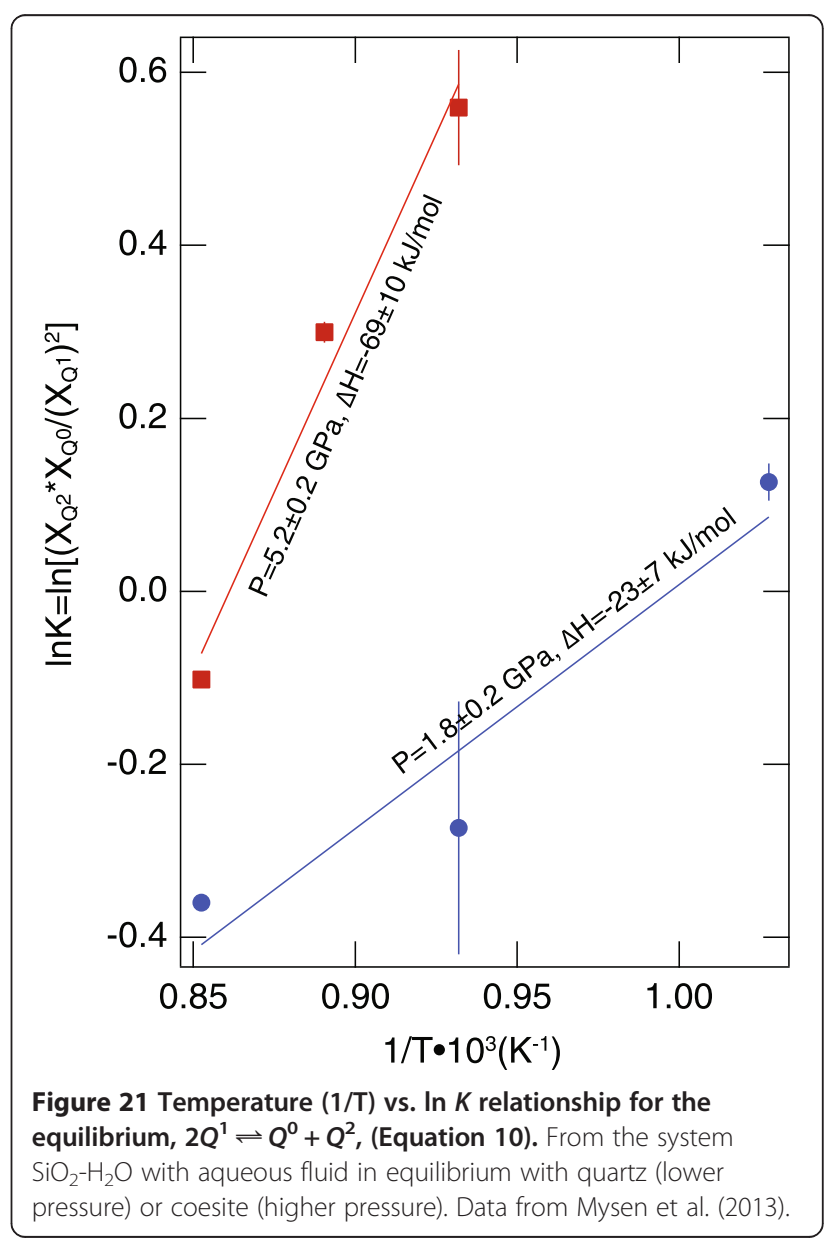


and $Q^{2}$ species are also observed (Mysen et al. 2013) with the $Q^{n}$ species equilibrium,

$$
2 Q^{1} \rightleftharpoons Q^{0}+Q^{2}
$$

for which the $\Delta H$ clearly is pressure dependent (Figure 21). The pressure $/ \Delta H$ relationship reflects the fact the $\Delta \mathrm{V}$ of reaction (10) is between -1 and $-2 \mathrm{~cm}^{3} / \mathrm{mol}$ (Mysen et al. 2013).

The system $\mathrm{SiO}_{2}-\mathrm{H}_{2} \mathrm{O}$ is too simple for modeling natural processes because neither $\mathrm{Al}_{2} \mathrm{O}_{3}$ nor alkali metals and alkaline earths are involved. The system $\mathrm{Na}_{2} \mathrm{O}$ $\mathrm{Al}_{2} \mathrm{O}_{3}-\mathrm{SiO}_{2}$ is more realistic even though alkaline earths, in particular, have not yet been addressed. The $\mathrm{Na}_{2} \mathrm{O}-$ $\mathrm{Al}_{2} \mathrm{O}_{3}-\mathrm{SiO}_{2}$ system is also useful for characterization of the chemical interaction between nonbridging oxygen and important network-modifying cation $\left(\mathrm{Na}^{+}\right)$and protons $\left(\mathrm{H}^{+}\right)$.

From NMR spectroscopy of quenched melts in this system, there is a strong preference of $\mathrm{H}^{+}$for nonbridging oxygen in the least polymerized of the $Q^{n}$ species $\left(Q^{0}\right)$, whereas $\mathrm{Na}^{+}$forms bonds with nonbridging oxygen in the more polymerized $Q^{n}$ species (Cody et al. 2005; see also Equation 7). From the in situ structural characterization in alkali aluminosilicate systems, a more complex reaction (Mysen 2010a)

$$
12 Q^{3}(\mathrm{M})+13 \mathrm{H}_{2} \mathrm{O} \rightleftharpoons 2 Q^{2}(\mathrm{M})+6 Q^{1}(\mathrm{M})+4 Q^{0}(\mathrm{H}),
$$

describes the equilibrium. Here, $M$ denotes an alkali metal and where $(\mathrm{M})$ and $(\mathrm{H})$ indicate where alkali metals and protons form bonding with the relevant nonbridging oxygens, respectively. The tetrahedrally coordinated cations forming the $Q^{n}$ species can be either $\mathrm{Al}^{3+}$ or $\mathrm{Si}^{4+}$. The $\Delta H$ for this equilibrium (350 to $400 \mathrm{~kJ} / \mathrm{mol}$ ) is the same, within uncertainty for melt fluids and supercritical fluids (Mysen 2010a). With increasing $\mathrm{Al} /(\mathrm{Al}+\mathrm{Si}$ ), equilibrium (11) likely shifts to the left ( $\Delta H$ decreases) because $\mathrm{Al}^{3+}$ will preferably occupy the most polymerized of available $Q^{n}$ species (Merzbacher and White 1991). In Equation 11, that species is $Q^{3}$, but for other more polymerization melt compositions, $Q^{4}$ species likely also would be involved. The principles outlined in equilibrium (11) may also be applied to alkaline earths, but quantitative information awaits further experiments. These are all considerations necessary for the application of the experimental data to hydrous magmatic systems. However, the necessary experimental data are at present insufficiently comprehensive for quantitative application.

\section{Discussion}

\section{Dissolved water and melt properties}

The evolution of $Q^{n}$ species abundance of a melt with water content can be used to characterize how dissolved water governs phase relations and mixing properties of melts. For example, the rapid abundance increase of depolymerized species at the expense of polymerized species with water content of the melt enhances the stability of depolymerized relative to more polymerized liquidus phases. An example of this effect can be seen in the silica/pyroxene liquidus boundary of the $\mathrm{Mg}_{2} \mathrm{SiO}_{4}$ $\mathrm{CaMgSi}_{2} \mathrm{O}_{6}-\mathrm{SiO}_{2}$ system where the silica polymorph is more polymerized than pyroxene (their $\mathrm{NBO} / \mathrm{Si}$ are 0 and 2, respectively) (Figure 2A). The magnitude of liquidus boundary shifts will reflect the size of the $\mathrm{NBO} / \mathrm{Si}$ difference between the minerals coexisting along a liquidus boundary. The greater the $\mathrm{NBO} / \mathrm{Si}$ difference, the greater is the effect of water on the shift of the boundary as illustrated, for example, by the different shifts of olivine/pyroxene and pyroxene/silica liquidus boundaries (Kushiro 1969). Effects such as these also explain why hydrous melts in equilibrium with peridotite mineral assemblages is more silica rich (quartz normative andesitic melts) than under anhydrous conditions (olivine normative tholeiitic melts) during melting and crystallization in the upper mantle.

Configurational properties of melts can be linked to transport and thermodynamic properties of melts (Adam and Gibbs 1965; Richet 1984; Lee and Stebbins 1999). For example, melt viscosity, $\eta$, is a function of configurational entropy:

$$
\eta=A_{e} \exp \left(B_{e} / T S^{\text {conf }}\right)
$$

where $A_{e}$ and $B_{e}$ are constants, $T$ is temperature, and $S^{\text {conf }}$ is configurational entropy. The $S^{\text {conf }}$ is described in terms of configurational heat capacity:

$$
S^{\text {conf }}(T)=\left[C_{p}^{\text {conf }}\left(T_{g}\right) / T_{g}\right]+\int_{T_{g}}^{T}\left(C_{p}^{\text {conf }} / T\right) d T,
$$

where $T_{\mathrm{g}}$ is glass transition temperature, $T$ is the temperature of interest $\left(T>T_{\mathrm{g}}\right)$, and $C_{\mathrm{p}}{ }^{\text {conf }}\left(T_{\mathrm{g}}\right)$ is the configurational heat capacity at the glass transition temperature. This configurational heat capacity of hydrous magmatic melts is a systematic function of the water content of the melt (Richet et al. 1996; Bouhifd et al. 2006).

Changes in configurational heat capacity resulting from $\mathrm{H}_{2} \mathrm{O}$ dissolved in the melt can be calculated from the experimental data on $Q^{n}$ species abundance in hydrous melts combined with the knowledge of the partial molar heat capacity of individual species (Richet and Neuville 1992; see also Mysen 2007). For example, with such information, the effects of water on the heat capacity change across the glass transition measured for a 


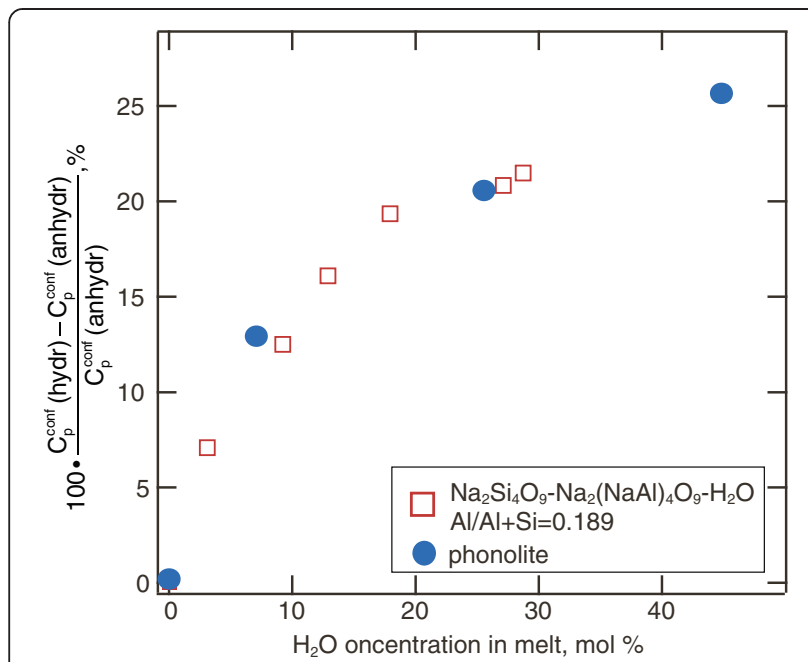

Figure 22 Calculated and observed change of configuration heat capacity. Comparison of calculated and observed change of configuration heat capacity, $C_{p}$,onf across the glass transition for a hydrous phonolite melt as a function of water content of the melt. Experimental data for phonolite from Bouhifd et al. (2006). Structural and thermodynamic data used to derive partial molar configurational entropy of $Q^{n}$ species are from Mysen (2010a) and Richet and Neuville (1992), respectively. This calculation was originally reported in Mysen (2007).

phonolite melt can be modeled quite precisely from a hydrous haplophonolitic composition in the $\mathrm{Na}_{2} \mathrm{O}-\mathrm{Al}_{2} \mathrm{O}_{3}-$ $\mathrm{SiO}_{2}$ system (Figure 22). The $\mathrm{NBO} / \mathrm{T}$ and $\mathrm{Al} /(\mathrm{Al}+\mathrm{Si}$ ) of this haplophonolite melt resemble that of the natural phonolite melt composition. The good match between calculated and observed configurational heat capacity changes with water content illustrates how those compositional parameters are central to characterization of configurational properties of melts.
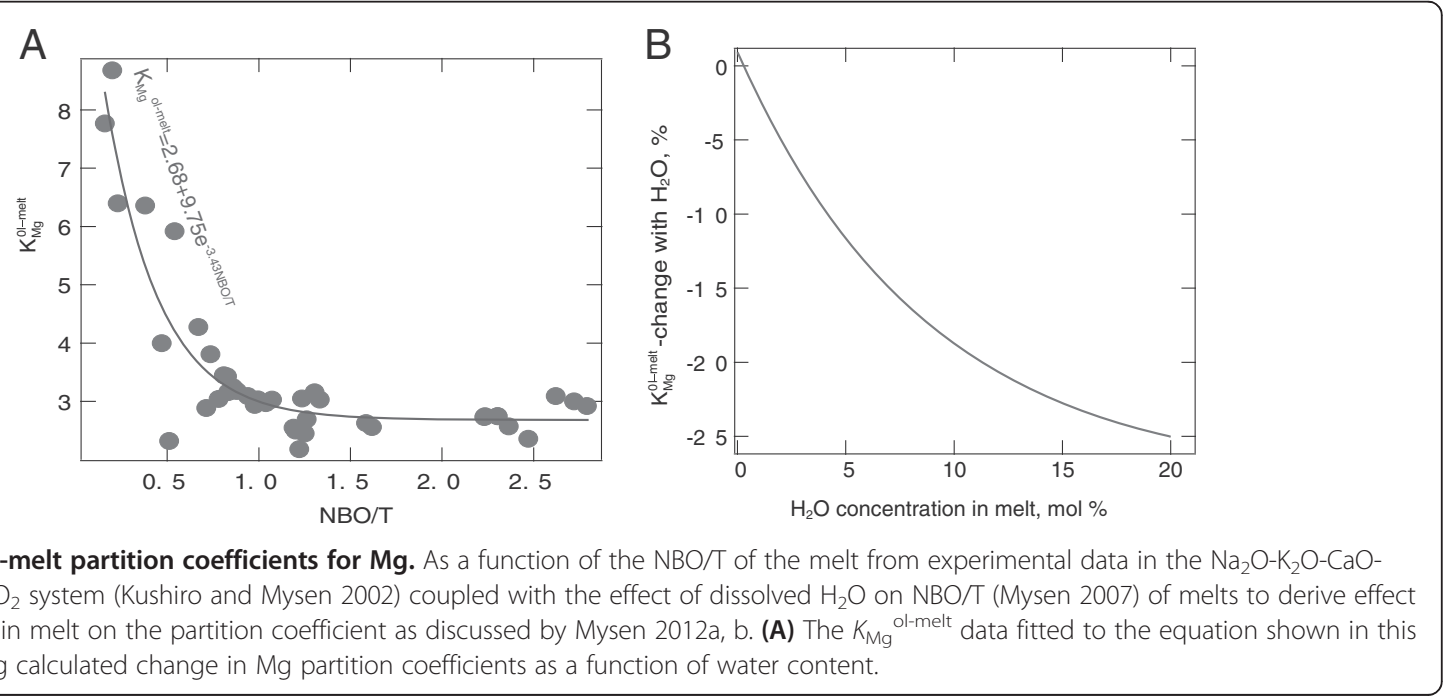

Figure 23 Olivine-melt partition coefficients for $\mathbf{M g}$. As a function of the $\mathrm{NBO} / \mathrm{T}$ of the melt from experimental data in the $\mathrm{Na}_{2} \mathrm{O}-\mathrm{K}_{2} \mathrm{O}-\mathrm{CaO}-$ $\mathrm{MgO}-\mathrm{FeO}-\mathrm{Al}_{2} \mathrm{O}_{3}-\mathrm{SiO}_{2}$ system (Kushiro and Mysen 2002) coupled with the effect of dissolved $\mathrm{H}_{2} \mathrm{O}$ on NBO/T (Mysen 2007) of melts to derive effect of dissolved water in melt on the partition coefficient as discussed by Mysen 2012a, b. (A) The $K_{\mathbf{M g}}{ }^{\text {ol-melt }}$ data fitted to the equation shown in this figure. (B) Resulting calculated change in Mg partition coefficients as a function of water content.

\section{Water and fluid-melt equilibria}

Trace and minor element partitioning is also sensitive to melt polymerization (Mysen and Virgo 1980; Kohn and Schofield 1994; Jaeger and Drake 2000; Toplis and Corgne 2002). From the relationship between $\mathrm{NBO} / \mathrm{T}$ and water contents of such melts

$$
\mathrm{NBO} / \mathrm{T}=1.10-0.57 \cdot e^{-0.068 X_{\mathrm{H}_{2} \mathrm{O}}},
$$

and $\mathrm{NBO} / \mathrm{T}$ and $K_{\mathrm{Mg}}{ }^{\text {ol-melt }}$ (Kushiro and Mysen 2002; see also Figure 23A), changes in the olivine/melt partition coefficient with water content can be calculated (Figure 23B). In the calculation in Figure 23, it is assumed that there is no structural interaction between the silicate components and the element in question $(\mathrm{Mg})$. Under such circumstances, the $\mathrm{NBO} / \mathrm{T}$ changes in melt have effects on partition coefficients in ways analogous to $\mathrm{NBO} / \mathrm{T}$ changes affected by adding other oxide components. The $25 \%$ change in the $\mathrm{Mg}$ partition, which reached with near $20 \mathrm{~mol} \% \mathrm{H}_{2} \mathrm{O}$, is not an unreasonable situation during island arc melting and crystallization (see, for example, Grove et al. 2012, for review of data).

\section{Stable isotope fractionation}

Vibrational spectroscopy has also been used to determine $\mathrm{D} / \mathrm{H}$ ratios in fluids and melts in equilibrium during experiments in diamond anvil cells at the high temperatures and pressures of interest (Foustoukos and Mysen 2012; Mysen 2013). In silicate-saturated fluids and hydrous silicate melts, $\mathrm{D}^{+}$and $\mathrm{H}^{+}$forms bonding with nonbridging oxygen in the $Q^{n}$ species. From deuterium and proton MAS NMR of silicate melts, a $\mathrm{D} / \mathrm{H}$ fractionation between the different structural positions has been found (Wang et al. 2011). This means that if the proportion and/or type of $Q^{n}$ species vary with temperature and/or pressure so that the $\mathrm{D} / \mathrm{H}$ fractionation within and between fluids and 

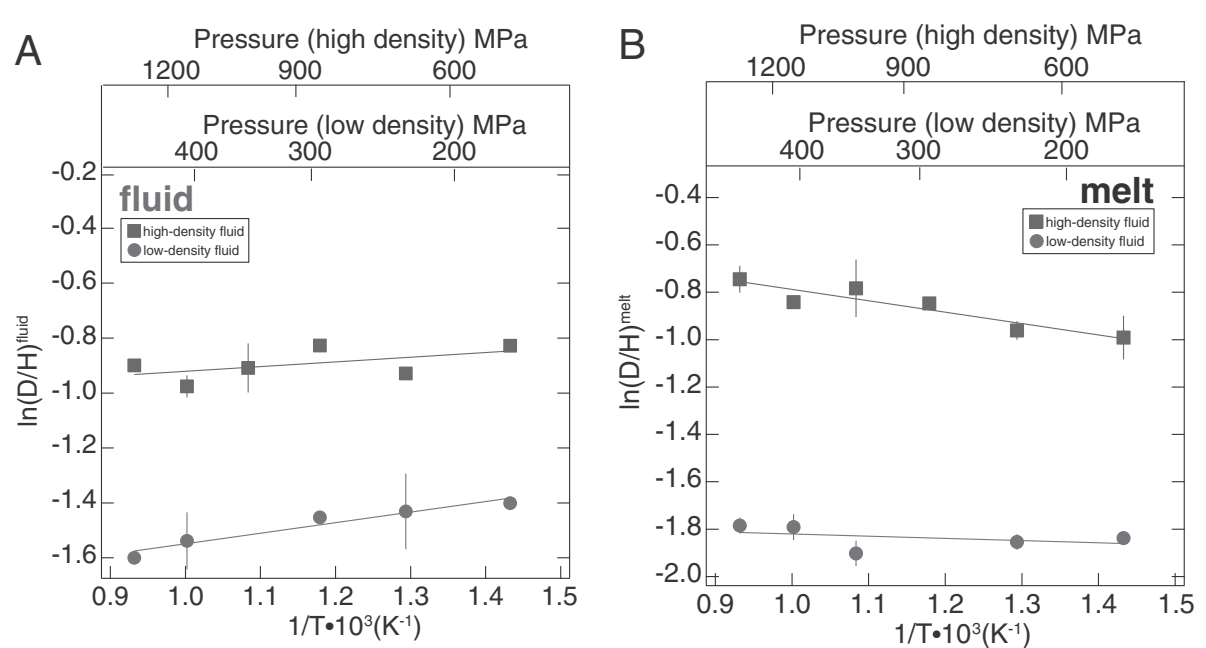

Figure 24 Evolution of $D / H$ ratio of coexisting fluid $(A)$ and melt $(B)$ for $\left(\mathrm{H}_{2} \mathrm{O}+\mathrm{D}_{2} \mathrm{O}\right)$-bearing Na-aluminosilicate melts. As a function of different fluid densities. In these experiments, the fluid density governs the relationship between temperature and pressure as shown in the figures. Data from Mysen 2013.

melts also become temperature and pressure dependent (Figures 24 and 25).

The temperature and pressure effects in Figure 24 reflect the changes in silicate concentration and speciation in the coexisting aqueous fluid and silicate melts. Furthermore, different $\mathrm{D} / \mathrm{H}$ values for different fluid densities again reflect the concentration and type of $Q^{n}$ species

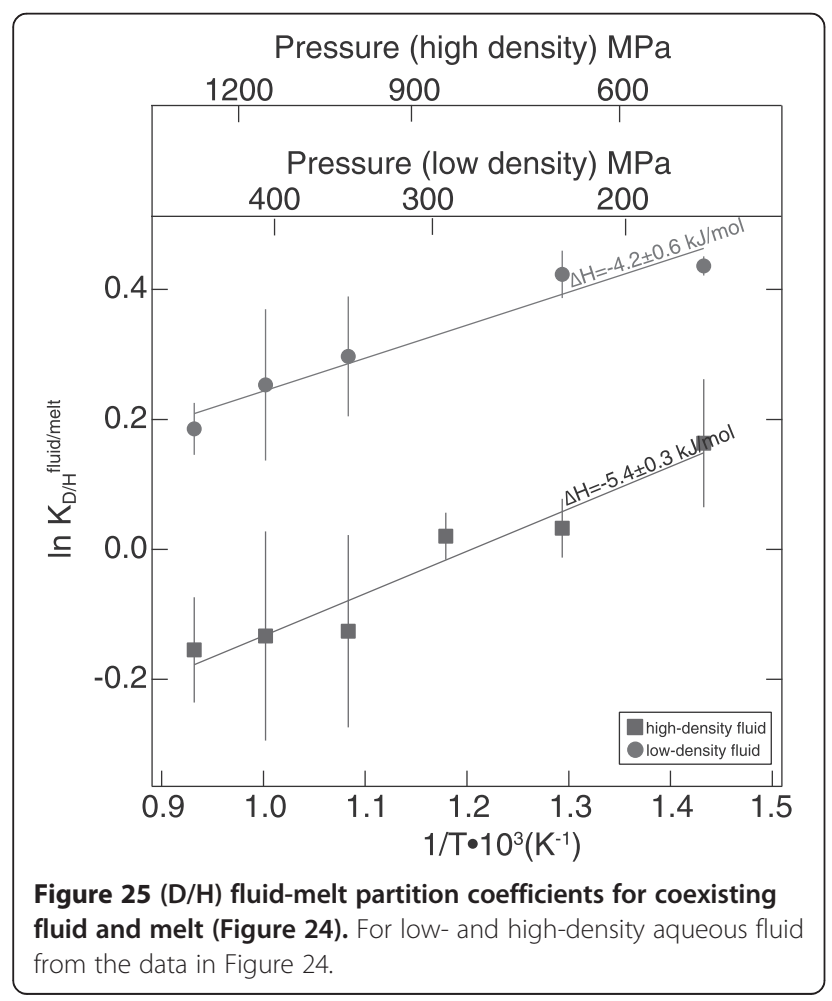

because the different density trajectories reflect pressure/ temperature trajectories of the diamond cell experiments that followed different pressure paths (Mysen 2013). It follows from the different trajectories of $\mathrm{D} / \mathrm{H}$ ratios in fluids and melts that the $\mathrm{D} / \mathrm{H}$ partitioning between fluids and melts will also be dependent on temperature and pressure (Figure 25). Finally, in silicate mineral/aqueous fluid or silicate mineral/hydrous melt environments, temperatureand pressure-dependent partitioning will also take place because of the temperature/pressure dependence of the $\mathrm{D} / \mathrm{H}$ fractionation with the fluid and melt phases.

\section{Conclusions}

Understanding the role of hydrous melts and silicaterich fluids in transport processes depends sensitively on how chemical composition, temperature, and pressure govern the physicochemical properties of these materials (viscosity, diffusion, thermodynamics of mixing, element partitioning between phases, phase relations, etc.; see, for example, Mysen and Richet 2005, for review of experimental and theoretical information of structure-property relations of silicate glasses and melts). Attainment of this objective requires well-determined solubilities in and partitioning between melts, fluids, and crystalline phases, detailed understanding of the oxide solution mechanisms in melts and fluids, and determination of how fluid and melt structure governs those properties.

Structural information cannot be obtained directly on chemically complex natural systems because the resolving power of spectroscopic methods employed for such purposes diminishes rapidly with increasing chemical complexity. However, structural data from simpler binary 
and ternary systems can be used to describe the more complex systems. This objective requires, however, detailed characterization of silicate speciation in fluids and melts as a function of $\mathrm{Al} / \mathrm{Si}$ ratio, the type of charge balance for tetrahedrally coordinated cations, and the type and proportion of network-modifying metals (alkali metals and alkaline earths). Currently, a combination of structural information and empirical relationships can be applied to describe liquidus phase relations and fluid/mineral/melt element and stable isotope partitioning. Transport properties can be understood and sometimes quantified in terms of configurational properties of individual $Q^{n}$ species. However, the experimental database used for these purposes dominantly is from alkali silicate and alkali aluminosilicate systems. This permits application to felsic magmatic systems. However, the lack of much information in alkaline earth aluminosilicate system makes quantitative application to hydrous basaltic less quantitative.

\section{Competing interests}

The author declares that he has no competing interests.

\author{
Acknowledgements \\ Many of the ideas and conclusions discussed in this review were developed \\ during the preparation of invited lectures at Tohoku University, Japan in \\ 2013. Portions of the reviewed research were supported by grants from the \\ National Science Foundation (US) (EAR-0707861, EAR1250449, EAR12151931 \\ and EAR-1212754)
}

Received: 3 December 2013 Accepted: 10 March 2014 Published: 22 April 2014

\section{References}

Adam G, Gibbs JH (1965) On the temperature dependence of cooperative relaxation properties in glass-forming liquids. J Chem Phys 43:139-146

Antignano A, Manning CE (2008) Rutile solubility in $\mathrm{H}_{2} \mathrm{O}, \mathrm{H}_{2} \mathrm{O}-\mathrm{SiO}_{2}$, and $\mathrm{H}_{2} \mathrm{O}$ $\mathrm{NaAlSi}_{3} \mathrm{O}_{8}$ fluids at 0.7-2.0 GPa and 700-1000 degrees $\mathrm{C}_{\text {; implications for }}$ mobility of nominally insoluble elements. Chem Geol 255:283-293

Audetat A, Keppler H (2004) Viscosity of fluids in subduction zones. Science 303:513-516

Audetat A, Keppler H (2005) Solubility of rutile in subduction zone fluids, as determined by experiments in the hydrothermal diamond anvil cell. Earth Planet Sci Lett 232:393-402

Ayers JC, Watson EB (1993) Apatite/fluid partitioning of rare-earth elements and strontium; experimental results at $1.0 \mathrm{GPa}$ and 1000 degrees $C$ and application to models of fluid-rock interaction. Chem Geol 110:299-314

Bassett WA, Shen AH, Bucknum M, Chou IM (1994) A new diamond cell for hydrothermal studies to $2.5 \mathrm{GPa}$ and from $-190^{\circ} \mathrm{C}$ to $1200^{\circ} \mathrm{C}$. Rev Sci Instrum 64:2340-2345

Behrens H, Jantos N (2001) The effect of anhydrous composition on water solubility in granitic melts. Amer Miner 86:14-20

Behrens H, Nowak M (1997) The mechanisms of water diffusion in polymerized silicate melts. Contrib Miner Petrol 126:377-385

Behrens H, Meyer M, Holtz F, Nowak M (2001) The effect of alkali ionic radius, temperature, and pressure on the solubility of water in $\mathrm{MAISi}_{3} \mathrm{O}_{8}$ melts ( $M=L i, N a, K, R b)$. Chem Geol 174:275-289

Bernini D, Audetat A, Dolejs A, Keppler H (2013) Zircon solubility in aqueous fluids at high temperatures and pressures. Geochim Cosmochim Acta 119:178-187

Boettcher AL (1984) The system $\mathrm{SiO}_{2}-\mathrm{H}_{2} \mathrm{O}-\mathrm{CO}_{2}$ : Melting solubility mechanisms of carbon and liquid structure to high pressures. Amer Miner 69:823-834

Bottinga Y, Richet P (1995) Silicate melts: The "anomalous" pressure dependence of the viscosity. Geochim Cosmochim Acta 59:2725-2732
Bouhifd MA, Whittington A, Roux J, Richet P (2006) Effect of water on the heat capacity of polymerized aluminosilicate glasses and melts. Geochem Cosmochim Acta 70:711-722

Boyd FR, England JL, Davis BCT (1964) Effect of pressure on the melting and polymorphism of enstatite, $\mathrm{MgSiO}_{3}$. J Geophys Res 69:2101-2109

Buckermann W-A, Muller-Warmuth W, Frischat GH (1992) A further ${ }^{29}$ Si MAS NMR study on binary alkali silicate glasses. Glasstechnische Bericht 65:18-21

Bureau H, Keppler H (1999) Complete miscibility between silicate melts and hydrous fluids in the upper mantle; experimental evidence and geochemical implications. Earth Planet Sci Lett 165:187-196

Burnham CW (1975) Thermodynamics of melting in experimental silicate-volatile systems. Geochim Cosmochim Acta 39:1077-1084

Cody GD, Mysen BO, Lee SK (2005) Structure vs. composition: A solid state ${ }^{1} \mathrm{H}$ and ${ }^{29} \mathrm{Si} \mathrm{NMR}$ study of quenched glasses along the $\mathrm{Na}_{2} \mathrm{O}-\mathrm{SiO}_{2}-\mathrm{H}_{2} \mathrm{O}$ join. Geochim Cosmochim Acta 69:2373-2384

Dingwell DB, Webb SL (1990) Relaxation in silicate melts. Eur J Mineral 2:427-449

Dixon JE, Stolper EM (1995) An experimental study of water and carbon dioxide solubilities in mid-ocean ridge basaltic liquids; Part II, Applications to degassing. J Petrol 36:1633-1646

Einstein A (1905) Über die von der molekular-kinetischen Theorie der Wärme geforderte Bewegung von in ruhenden Flüssigkeiten suspendierten Teilchen. Ann Phys 17:549-560

Eyring H (1935a) The activated complex in chemical reactions. J Chem Phys 3:107-115

Eyring $H$ (1935b) The activated complex and the absolute rate of chemical reactions. Chem Rev 17:65-77

Farnan I, Kohn SC, Dupree R (1987) A study of the structural role of water in hydrous silica using cross-polarisation magic angle NMR. Geochim Cosmochim Acta 51:2869-2874

Foustoukos DI, Mysen BO (2012) D/H isotopic fractionation in the $\mathrm{H}_{2}-\mathrm{H}_{2} \mathrm{O}$ system at supercritical water conditions: Composition and hydrogen bonding effects. Geochim Cosmochim Acta 86:88-102

Foustoukos DI, Mysen BO (2013) H/D methane isotopologues dissolved in magmatic fluids: Stable hydrogen isotope fractionations in the Earth's interior. Amer Miner 98:946-954

Grove TL, Elkins-Stanton LT, Parman SW, Chatterjee N, Muntner O, Gaetani GA (2003) Fractional crystallization and mantle-melting controls on calc-alkaline differentiation trends. Contrib Miner Petrol 145:515-543

Grove TL, Till CB, Krawczynski MJ (2012) The roleof $\mathrm{H}_{2} \mathrm{O}$ in subduction zone magmatism. Ann Rev Earth Planet Sci 40:413-439

Hack A, Thompson AB (2012) Density and viscosity of hydrous magmas and related fluids and their role in subduction zone processes. J Petrol 52:13331362

Hamilton DL, Burnham CW, Osborn EF (1964) The solubility of water and the effects of oxygen fugacity and water content on crystallization of mafic magmas. J Petrol 5:21-39

Hess K-U, Dingwell DB (1996) Viscosities of hydrous leucogranitic melts: A non-Ahrrenian model. Amer Miner 81:1297-1300

Holloway JR, Jakobsson S (1986) Volatile solubilities in magmas: Transport of volatiles from mantles to planet surfaces. J Geophys Res 91:505-508

Holtz F, Behrens H, Dingwell DB, Johannes W (1995) $\mathrm{H}_{2} \mathrm{O}$ solubility in haplogranitic melts: Compositional, pressure, and temperature dependence. Amer Miner 80:94-108

Hunt JD, Manning CE (2012) A thermodynamic model for the system $\mathrm{SiO}_{2}-\mathrm{H}_{2} \mathrm{O}$ near the upper critical end point based on quartz solubility experiments at 500-1100 degrees C and 5-20 kbar. Geochim Cosmochim Acta 86:196-213

Jackson I (1976) Melting of the silica isotypes $\mathrm{SiO}_{2}, \mathrm{BeF}_{2}$ and $\mathrm{GeO}_{2}$ at elevated pressures. Phys Earth Planet Int 13:218-231

Jaeger WL, Drake MJ (2000) Metal-silicate partitioning of Co, Ga, and W; dependence on silicate melt composition. Geochim Cosmochim Acta 64(22):3887-3895

Kawamoto T, Ochiai S, Kagi H (2004) Changes in the structure of water deduced from the pressure dependence of the Raman $\mathrm{OH}$ frequency. J Chem Phys 120:5867-5870

Kennedy GC, Wasserburg GJ, Heard HC, Newton RC (1962) The upper threephase region in the system $\mathrm{SiO}_{2}-\mathrm{H}_{2} \mathrm{O}$. Amer J Sci 260:501-521

Kohn SC, Schofield PF (1994) The importance of melt composition in controlling trace-element behaviour: An exprimental study of $\mathrm{Mn}$ and $\mathrm{Zn}$ partitioning between forsterite and silicate melt. Chem Geol 117:73-87

Kurkjian CR, Russell LE (1958) Solubility of water in molten alkali silicates. J Soc Glass Techn 42:130T-144T 
Kushiro I (1969) The system forsterite-diopside-silica with and without water at high pressures. Amer J Sci 267-A:269-294

Kushiro I (1972) Effect of water on the composition of magmas formed at high pressures. J Petrol 13:311-334

Kushiro I (1990) Partial melting of mantle wedge and evolution of island arc crust. J Geophys Res 95:15929-15939

Kushiro I, Mysen BO (2002) A possible effect of melt structure on the Mg-Fe ${ }^{2+}$ partitioning between olivine and melt. Geochim Cosmochim Acta 66:2267-2273

Kushiro I, Yoder HS, Nishikawa M (1968a) Effect of water on the melting of enstatite. Geol Soc Amer Bull 79:1685-1692

Kushiro I, Syono Y, Akimoto SI (1968b) Melting of a peridotite nodule at high pressures and high water pressures. J Geophys Res 73:6023-6029

Lee SK, Stebbins JF (1999) The degree of aluminum avoidance in aluminum silicate glasses. Amer Miner 84:937-945

Lee SK, Cody GD, Fei Y, Mysen BO (2004) Nature of polymerization and properties of silicate melts at high pressure. Geochem Cosmochim Acta 68:4189-4200

Luth WC, Jahns RH, Tuttle OF (1964) The granite system at pressures of 4 to 10 kilobars. J Geophys Res 69:759-773

Maekawa H, Maekawa T, Kawamura K, Yokokawa T (1991) The structural groups of alkali silicate glasses determined from ${ }^{29} \mathrm{Si} \mathrm{MAS-NMR.} \mathrm{J} \mathrm{Non-Cryst} \mathrm{Solids}$ 127(1):53-64

Manning CE (1994) The solubility of quartz in $\mathrm{H} 2 \mathrm{O}$ in the lower crust and upper mantle. Geochim Cosmochim Acta 58:4831-4840

Manning CE (2004) The chemistry of subduction-zone fluids. Earth Planet Sci Lett 223:1-16

McMillan PF (1994) Water solubility and speciation models. In: Carroll MR, Holloway JR (ed) Volatiles in magmas. Mineralogical Society of America, Washington DC, pp 131-156

McMillan PF, Holloway JR (1987) Water solubility in aluminosilicate melts. Contr Miner Petrol 97:320-332

Merzbacher Cl, White WB (1991) The structure of alkaline earth aluminosilicate glasses as determined by vibrational spectroscopy. J Non-Cryst Solids 130:18-34

Mibe K, Kanzaki M, Kawamoto T, Matsukage KN, Fei Y, Ono S (2007) Second critical endpoint in the peridotite-H2O system. J Geophys Res 112. doi: 10.1029/2005JB004125

Moulson AJ, Roberts JP (1961) Water in silica glass. Trans Faraday Soc 57:1208-1216

Mysen BO (2002) Water in peralkaline aluminosilicate melts to $2 \mathrm{GPa}$ and $1400^{\circ} \mathrm{C}$. Gechim Cosmochim Acta 66:2915-2928

Mysen BO (2007) The solution behavior of $\mathrm{H} 2 \mathrm{O}$ in peralkaline aluminosilicate melts at high pressure with implications for properties of hydrous melts. Geochim. Cosmochim. Acta, 71, 1820-1834. Geochim Cosmochim Acta 71:1820-1834

Mysen $\mathrm{BO}$ (2009) Solution mechanisms of silicate in aqueous fluid and $\mathrm{H}_{2} \mathrm{O}$ in coexisting silicate melts determined in-situ at high pressure and high temperature. Geochim Cosmochim Acta 73:5748-5763

Mysen $\mathrm{BO}(2010 \mathrm{a})$ Structure of $\mathrm{H}_{2} \mathrm{O}$-saturated peralkaline aluminosilicate melt and coexisting aluminosilicate-saturated aqueous fluid determined in-situ to $800^{\circ} \mathrm{C}$ and $\sim 800 \mathrm{MPa}$. Geochim Cosmochim Acta 74:4123-4139

Mysen BO (2010b) Speciation and mixing behavor of silica-saturated aqueous fluid at high temperature and pressure. Amer Miner 95:1807-1816

Mysen BO (2011) An experimental study of phosphorous and aluminosilicate speciation in and partitioning between aqueous fluids and silicate melts determined in-situ at high temperature and pressure. Amer Miner 96:1636-1649

Mysen BO (2012a) High-pressure/-temperature titanium solution mechanisms in silicate-saturated aqueous fluids and hydrous silicate melts. Amer Miner 97:1241-1251

Mysen BO (2012b) Silicate-COH melt and fluid structure, their physicochemical properties, and partitioning of nominally refractory oxides between melts and fluids. Lithos 148:228-246

Mysen BO (2013) Hydrogen isotope fractionation between coexisting hydrous melt and coexisting silicate-saturated aqueous fluid: An experimental study in-situ at high pressure and temperature. Amer Miner 98:376-386

Mysen BO, Virgo D (1980) Trace element partitioning and melt structure; an experimental study at $1 \mathrm{~atm}$ pressure. Geochim Cosmochim Acta 44(12):1917-1930

Mysen BO, Virgo D (1986) Volatiles in silicate melts at high pressure and temperature. 1. Interaction between $\mathrm{OH}$ groups and $\mathrm{Si}^{4+}, \mathrm{Al}^{3+}, \mathrm{Ca}^{2+}, \mathrm{Na}^{+}$and $\mathrm{H}^{+}$. Chem Geol 57:303-331
Mysen BO, Wheeler K (2000) Solubility Behavior of Water in Haploandesitic Melts at high Pressure and high Temperature. Amer Miner 85:1128-1142

Mysen BO, Cody GD (2004) Solubility and solution mechanism of $\mathrm{H}_{2} \mathrm{O}$ in alkali silicate melts and glasses at high pressure and temperature. Geochem Cosmochim Acta 68:5113-5126

Mysen BO, Richet P (2005) Silicate glasses and melts: properties and structure. Developments in geochemistry. Elsevier, New York

Mysen BO, Mibe K, Chou I-M, Bassett WA (2013) Structure and equilibria among silicate species in aqueous fluids in the upper mantle: Experimental $\mathrm{SiO}_{2}-\mathrm{H}_{2} \mathrm{O}$ and $\mathrm{MgO}-\mathrm{SiO}_{2}-\mathrm{H}_{2} \mathrm{O}$ data recorded in-situ to $900^{\circ} \mathrm{C}$ and $5.4 \mathrm{GPa}$. J Geophys Res 118. doi:10.1002/2013JB010537

Nernst W (1888) Zur Kinetik der in lösung befindtlicher Körper. Erste Abhandlung, Theorie der Diffusion. Z Phys Chem 2:613-637

Newton RC, Manning CE (2002) Solubility of enstatite+forsterite in $\mathrm{H}_{2} \mathrm{O}$ in deep crust/upper mantle conditions: 4 to $15 \mathrm{kbar}$ and 700 to $900^{\circ} \mathrm{C}$. Geochim Cosmochim Acta 66:4165-4176

Newton RC, Manning CE (2008) Solubility of corundum in the system $\mathrm{Al}_{2} \mathrm{O}_{3}$ $\mathrm{SiO}_{2}-\mathrm{H}_{2} \mathrm{O}-\mathrm{NaCl}$ at $800{ }^{\circ} \mathrm{C}$ and $10 \mathrm{kbar}$. Chem Geol 249:250-261

Nowak M, Behrens H (1995) The speciation of water in haplogranitic glasses and melts by in-situ, near-infrared spectroscopy. Geochim Cosmochim Acta 59:3445-3450

Ochs FA, Lange RA (1999) The density of hydrous magmatic liquids. Science 283:1314-1317

Ohtani E, Taulelle F, Angell CA (1985) $\mathrm{Al}^{3+}$ coordination changes in liquid silicates under pressure. Nature 314:78-81

Pascal ML, Anderson GM (1989) Speciation of Al, Si, and K in supercritical solutions: Experimental study and interpretation. Geochim Cosmochim Acta 53:1843-1856

Poli S, Schmidt MW (2002) Petrology of subducted slabs. Ann Rev Earth Planet Sci 30:207-235

Richet P (1984) Viscosity and configurational entropy of silicate melts. Geochim Cosmochim Acta 48:471-483

Richet P, Neuville DR (1992) Thermodynamics of silicate melts: configurational properties. In: Saxena SK (ed) Thermodynamic data: systematics and estimation. Advances in physical geochemistry, vol 10. Springer, New York, pp 132-161

Richet P, Lejeune A-M, Holtz F, Roux J (1996) Water and the viscosity of andesite melts. Chem Geol 128:185-197

Richet P, Neuville DR, Holtz F (1997) Viscosity of water-bearing melts. Terra Nova Abstr Supple 9(480)

Roy BN, Navrotsky A (1984) Thermochemistry of charge-coupled substitutions in silicate glasses:-The systems $\mathrm{Mn}_{\mathrm{n}}^{\mathrm{n}+} \mathrm{AlO}_{2}-\mathrm{SiO}_{2}(\mathrm{M}=\mathrm{Li}, \mathrm{Na}, \mathrm{K}, \mathrm{Rb}, \mathrm{Cs}, \mathrm{Mg}, \mathrm{Ca}, \mathrm{Sr}$, $\mathrm{Ba}, \mathrm{Pb})$. J Amer Ceram Soc 67:606-610

Satherley K, Smedley SI (1985) The electrical conductivity of some hydrous and anhydrous molten silicates-as a function of temperature and pressure. Geochim Cosmochim Acta 49:769-777

Schmidt BC, Riemer T, Kohn SC, Holtz F, Dupree R (2001) Structural implications of water dissolution in haplogranitic glasses from NMR spectroscopy: Influence of total water content and mixed alkali effect. Geochim Cosmochim Acta 65:2949-2964

Spallanzani L (1798) Viaggi alle Due Sicilie e in alcune parti dell' Appennino, transl. as Travels in the Two Sicilies and Some Parts of the Appenines, J. Robinson, London. Stamperia di B, Comini, Pavia

Spera FJ (1974) A thermodynamic basis for predicting water solubilties in silicatemelts and implications for the low velocity zone. Contr Mineral Petrol 45:175-186

Stebbins JF (1987) Identification of multiple structural species in silicate glasses by ${ }^{29}$ Si NMR. Nature 330:465-467

Stern CR, Huang W-L, Wyllie PJ (1975) Basalt-andesite-rhyolite- $\mathrm{H}_{2} \mathrm{O}$ : Crystallization intervals with excess $\mathrm{H}_{2} \mathrm{O}$ and $\mathrm{H}_{2} \mathrm{O}$-undersaturated liquidus surfaces to 35 kilobars, with implications for magma genesis. Earth Planet Sci Lett 28:189-196

Stolper E (1982) The speciation of water in silicate melts. Geochim Cosmochim Acta 46:2609-2620

Takata M, Acocella J, Tomozawa M, Watson EB (1981) Effect of water content on the electrical conductivity of $\mathrm{Na}_{2} \mathrm{O} \cdot 3 \mathrm{SiO}_{2}$ glass. J Amer Ceram Soc 64:719-724

Toplis MJ, Corgne A (2002) An experimental study of element partitioning between magnetite, clinopyroxene and iron-bearing silicate liquids with particular emphasis on vanadium. Contrib Mineral Petrol 144:22-37

Tuttle OF, Bowen NL (1958) Origin of granite in light of experimental studies in the system $\mathrm{NaAlSi}_{3} \mathrm{O}_{8}-\mathrm{KAISi}_{3} \mathrm{O}_{8}-\mathrm{SiO}_{2}-\mathrm{H}_{2} \mathrm{O}$. Geol Soc Amer Mem 74:1-153 
Virgo D, Mysen BO, Kushiro I (1980) Anionic constitution of 1-atmosphere silicate melts: implications of the structure of igneous melts. Science 208:1371-1373

Walrafen GE, Yang WH, Chu YC (1996) Raman OD-stretching overtone spectra from liquid $\mathrm{D}_{2} \mathrm{O}$ between 22 and 152 decrees $\mathrm{C}$. C. J Phys Chem 100:1381-1391

Wang YB, Cody SX, Cody GD, Mysen BO (2011) ${ }^{2} \mathrm{H}$ and ${ }^{1} \mathrm{H}$ NMR study on hydrogen isotope effects in silicate glasses. Paper presented at the 2011 AGU Fall Meeting, San Francisco, CA

Wasserburg GJ (1957) The effects of $\mathrm{H}_{2} \mathrm{O}$ in silicate systems. J Geol 65:15-23

Watson EB (1994) Diffusion in volatile-bearing magmas. In: Carroll MR, Holloway $J R$ (ed) Volatiles in magmas: reviews in mineralogy, 30th edition. Mineralogical Society of America, Washington, DC, pp 371-411

Whittington APR, Holtz F (2000) Water and the viscosity of depolymerized silicate melts. Geochim Cosmochim Acta 64:3725-3736

Xue Y, Kanzaki M (2004) Dissolution mechanisms of water in depolymerized silicate melts: Constraints from ${ }^{1} \mathrm{H}$ and ${ }^{29} \mathrm{Si}$ NMR spectroscopy and ab initio calculations. Geochim Cosmochim Acta 68:5027-5057

Zhang Y-G, Frantz JD (2000) Enstatite-forsterite-water equilibria at elevated temperatures and pressures. Amer Miner 85:918-925

Zhang $\mathrm{Y}$ (1999) $\mathrm{H}_{2} \mathrm{O}$ in rhyolitic glasses and melts: measurements, speciation, solubility, and diffusion. Rev Geophys Space Phys 37:493-516

Zotov N, Keppler H (1998) The influence of water on the structure of hydrous sodium tetrasilicate glasses. Amer Miner 83:823-834

doi:10.1186/2197-4284-1-4

Cite this article as: Mysen: Water-melt interaction in hydrous magmatic systems at high temperature and pressure. Progress in Earth and Planetary Science 2014 1:4.

\section{Submit your manuscript to a SpringerOpen ${ }^{\circ}$ journal and benefit from:}

- Convenient online submission

- Rigorous peer review

- Immediate publication on acceptance

- Open access: articles freely available online

- High visibility within the field

- Retaining the copyright to your article 